\title{
CIRCUM-BALTIC MYTHOLOGY? THE STRANGE CASE OF THE THEFT OF THE THUNDER-INSTRUMENT (ATU 1148B)*
}

\section{FROG}

\begin{abstract}
The myth of the Theft of the Thunder-Instrument (ATU 1148b) is found almost exclusively in the Circum-Baltic area. It is found among both Indo-European and Finno-Ugric cultures. This implies that it was adapted from one into the other, unless both assimilated it from a common cultural stratum. This paper surveys this mythological narrative tradition that is found in Baltic, Finnic, Germanic and Sámic cultures. It proposes that the tradition's persistence in a Circum-Baltic isogloss is a consequence of historical contact and interaction between these cultures, and that its evolution has been dependent on that history of contact and exchange.
\end{abstract}

Key words: comparative mythology, folklore, thunder-god, folk tale, cultural contact, Prymskviða.

The present paper ${ }^{1}$ is concerned with a narrative of mythological proportions: the Theft of the ThunderInstrument (ATU 1148b). ${ }^{2}$ The narrative may be summarised as follows:

A devil/giant steals the sleeping thunder-god's instrument (musical, mechanical or symbolic) and conceals it in his realm or home. The god assumes the disguise and role of a servant, either entering the service of the thief directly or entering the thief's house with his master. Others cannot play the instrument successfully. A

\footnotetext{
${ }^{1}$ I would like to thank Jūrate Šlekonytė, Aldis Putelis and Eila Stepanova for help in investigating sources in so many archives and so many languages - without them, this study would not have been possible. I would like to thank Professor Satu Apo for her comments and suggestions on an earlier version of this paper, and also Nijolè Laurinkiene. Finally, I would like to express my gratitude to Daiva Vaitkevičienè for the tremendous amount of time and attention which was required to make both the conference and this publication possible.

2 Initially approached as type 1148 'Der Teufel und der Donner (das Gewitter)’ (Aarne 1910, p.45; 1911, p.108); Thompson (1928, p.156) separated 1148 'The Ogre Afraid of the Thunder (the storm)' into subtypes A 'The ogre asks the man to tell him when it thunders. The man deceives him until at last the thunder kills him [K 1177]' and B, 'The ogre steals the thunder's instruments (pipe, sack, etc.) [G 610]'; Uther (2004 II, pp.48-50) reclassifies 1148 a as 1147 and titles 1148b 'Thunder's Instruments' with a synopsis based on the Estonian tradition (adding 'hammer' as a possible instrument). Cf. Thompson's (1955-1958) motifs A162.3 ('Combat between thundergod and devil'), A162.3.1 ('Devil (ogre) steals thunder's instruments'), A162.2 ('Thunder and lightning slay devils'), G610 ('Theft from ogre'), K1816.0.1 ('God disguised as menial'), also A189.1.1 ('Man as helper of thundergod').
}

challenge is initiated by either the host or the god (through his master). The host unwittingly provides the instrument to the god, expecting a positive return (entertainment). The god plays successfully, destroying the host, household and/or otherworld community.

ATU 1148b is found almost exclusively in CircumBaltic cultures among both Indo-European and FinnoUgric linguistic-cultural groups. This implies that it was adapted from one into the other, unless both assimilated it from a common cultural stratum. Whatever the case, ATU 1148b clearly crossed linguistic-cultural thresholds: examples are found among Sámic (Skolt, [possibly] Inari), Finnic (Finnish, Karelian, Estonian, Setu), Baltic (Latvian, Lithuanian) and Germanic (Icelandic, Faeroese, Norwegian, Danish, Swedish) language families in distinct conventional traditions (cf. Uther 2004 II, pp.9-50). However, ATU 1148b is not found among Slavic groups (cf. Barag et al. 1979, p.267), which have only held their increasingly significant presence in the Circum-Baltic for about the past millennium. ${ }^{3}$ ATU $1148 \mathrm{~b}$ is otherwise only attested in one early Greek poem, where it is combined with a narrative about the theft of Zeus's sinews. ${ }^{4}$

\footnotetext{
3 On possible Slavic parallels and the possible Rumanian parallel, see Balys (1939, pp.43-47, 51-52; cf. Krohn 1931, pp.127-128). These traditions and surrounding arguments will not be reviewed here.

4 U. Masing (1977) proposed that the Circum-Baltic ATU $1148 \mathrm{~b}$ is a special development of a widespread tradition of the struggle between the thunder-bird and a watermonster with a history of some 5,000 to 10,000 years. The treatment is speculative and not unproblematic (cf. Uther
} 
Koptjevskaja-Tamm and Wälchli (2001, p.622) emphasise that one of the interesting aspects of the Circum-Baltic region is that it 'has never been united, but has always been an extremely dynamic area, constantly redivided among spheres of dominance - economical, political, religious and cultural.' The overview of ATU 1148b offered here is intended to approach the relevance of that long history of cultural contact and exchange to mythology, beliefs and the narrative traditions through which these are communicated and maintained. Once overviews of the traditions as they survived and (when possible) how they evolved have been established, it will be possible to return to the observation of Koptjevskaja-Tamm and Wälchli in order to consider how histories of cultural interaction are relevant to the evolution of ATU $1148 \mathrm{~b}$ in the CircumBaltic arena.

\section{Circum-Baltic thunder-god tradi- tions}

According to Hans-Jörg Uther (1997-1999, p.763), narratives about thunder and a devil are especially prominent in Baltic, Finnic and Germanic cultures around the Baltic Sea. These narrative traditions are only one part of a remarkable system of thunder-related traditions distributed across diverse cultures in the region. These systems warrant detailed comparison, but only a few basic points will be presented here to provide some frame of reference. Oskar Loorits (1949-1957 II, p.5) suggested that the rise of the thunder-god to the supreme god among Finnic populations was attributable to Indo-European influences. ${ }^{5}$ Ülo Valk (1996) stresses that such influences may have been heavily stratified through interaction with multiple Indo-European cultures across history, and that such interactions were never one-sided. For example, Anna-Leena Siikala attributes the range and diversity of Germanic influences in Finno-Karelian mythology, epic and magic (where the thunder-god has a central role) primarily to processes of radical cultural change which took place across the Iron Age, when Germanic cultural influences were dominant (Siikala 2002a; Salo 2006; Frog 2010, pp.118-141; cf. Loorits 1949-1957 III, pp.286317). These influences dominate our field of vision in documented sources, but they no doubt overlaid earlier ethnocultural substrata (cf. Eila Stepanova's contribution to this volume). Conversely, the identification

1997-1999, p.764), and it stands beyond the scope of the present discussion.

5 See also Salo 1990, 2006. The anthropomorphic figure appears to have gradually displaced conceptions of a 'thunder-bird' (Loorits 1926, pp.51; 1949-1957 III, p.303n; Siikala 2002a, p.207). of a fire-striking stone in Thórr's head with the polar 'nail'-star is likely the result of reciprocal influence. ${ }^{6}$

Influences from Germanic or Baltic culture can appear quite clear in Finnic and Sámic cultures because the latter are assumed to lack Indo-European linguistic and cultural foundations. A comparison between Germanic and Baltic languages and traditions becomes more complex. For example, cognates with the name Perkūnas are readily recognisable in Finnic languages, ${ }^{7}$ as are cognates with Thórr. ${ }^{8}$ However, the vernacular Germanic name Fjorgyn (cognate with Pērkons/Perkūnas) is not a 'loan', yet the use of this name for Thórr's mother is likely under the ægis of Baltic influence (cf. Biezais 1972, p.95; West 2007, pp.241-242). Corresponding linguistic interference owing to phonetic resonance with Pērkons/Perkūnas may underlie Estonian Pikne, Pikäne, etc. ('Lightning') and Livonian Pikne ('Lightning') as central vernacular names for the thunder-god (cf. Loorits 1926, pp.49-50; 1949-1957 II, pp.8-9; Salo 2006, pp.9-12). Vladimir Toporov (1970) has plausibly argued that Thórr's companion Thjálfi crossed into Baltic traditions to become Perkūnas's smith-companion Teljavel' (Телявель). ${ }^{9}$ However, our perspective may be skewed because the majority of the sources for vernacular Germanic mythology are West Norse (roughly Norway, Iceland, etc.), rather than East Norse regions (roughly Denmark, Sweden, etc.), which were on the Baltic Sea. Place name evidence in Sweden discussed by Vykintas Vaitkevičius (2009) clearly shows separate patterns of interaction oriented eastward, hence it is not clear whether the Gotlandic (East Norse) Thjelvar (Pieluar) ${ }^{10}$ may have been more akin to Icelandic (West Norse) Thjálfi or (Old Lithuanian or its antecedent) Teljavel'.

Some features of the thunder-god appear almost universal in the Circum-Baltic, such as patriarchal epithets and the epithet 'Old Man' (even where he is

6 See examples and discussion in Tolley 2009, pp.275-276, 281; cf. Koch 1990; Salo 1990, pp.119-129; 2006, pp.3348. This motif and its history are complex and problematic. 7 Common nouns meaning 'devil' (Suomen sanojen alkuperä II, p.340, listing Swedish and Danish cognates; Loorits 1949-1957 II, p.13).

8 Sámic Horgalles ('Pórr karl', 'Old Man Thórr'), FinnoKarelian Tuuri, Estonian Tooru (Krohn 1915, pp.117118; Itkonen 1946, pp.2-3; de Vries 1956-1957 II, p.115; Bertell 2003, pp.73-81; Kulmar 2005, pp.24-28).

9 Mansikka 1922, pp.69-70; Vèlius 1996, p.266; cf. p.260; cf. also Biezais 1972, pp.130-131; Vèlius 1989, pp.52-53. For an overview of attempted etymologies, see Vèlius 1987, pp.206-207; 1996, pp.257-258.

10 Peel 1999, p.xvii-xviii, 2; for Östergötlandic (East Norse) Thjalfar (Pialfar), ibid.: 17; cf. also Rendahl 2001; on the world-creation imagery associated with Thjelvar, see Frog 2010, p.240. Note that throughout its history, Gotland has been an exceptional tradition area distinguishable from the rest of Germanic Scandinavia.

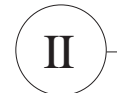

BALTIC WORLDVIEW: FROM MYTHOLOGY TO FOLKLORE 
described with a red beard). ${ }^{11}$ Other attributes of the god exhibit more complex patterns of relationships. For example, the axe or hammer is an attribute common to Germanic, Lithuanian (also sharing attributes of chariot and goats with Germanic), Finno-Karelian, and Sámic; in the midst of this, however, Latvian Pērkons has a ball or mace (milna, etymologically associated with Mjollnir, the name for Thórr's hammer) and Estonian Pikne plays a blown instrument (as in ATU 1148b, where it is often referred to simply as a pill ['instrument']). ${ }^{12}$ This distribution of attributes is of note because of the common inclination to systematise vernacular mythological systems - i.e. if an axe is an attribute of Finno-Karelian Ukko in one context or region, this should be valid for all contexts or regions (or else the tradition is 'corrupted' or has 'decayed'). However, Ukko's axe maintains prominence in certain fields of activity such as incantations and the widespread tradition of thunder-stones (Haavio 1967, p.332; Siikala 2002a, pp.204-208), while aetiological legends most often present the god's wagon as the source of thunder, never mentioning the curious objects or machine of ATU 1148b. In contrast, the pill is well established in Estonian and Setu traditions, where the axe attribute is absent, although there are also aetiologies of thunder associated with the god's wagon (Loorits 1949-1957 II, pp.22-25). The realities of circulating traditions often maintain several or even many parallel narratives, conceptions and beliefs, coexisting in a tradition ecology without a need to reconcile inconsistencies and contradictions, whether they are distributed in relation to contexts, functions and social groups, or are more actively competing with one another (Tarkka 2005, pp.160-194; Frog 2010, pp.230-231). This is sig-

${ }^{11}$ Krohn 1906, p.165; Holmberg [Harva] 1915, p.67; Loorits 1926, p.49; 1949-1957, pp.7-14; Harva 1948, pp.77-80; Haavio 1967, pp.161-164; Biezais 1972, p.111; Laurinkienė 1996, p.16; Bertell 2003, pp.73-81; Salo 2006, pp.8-9. The lack of evidence for this epithet in medieval Germanic sources in spite of the (apparent) loan into Sámi may be attributable to regional biases of the early (West Norse) sources (cf. Nordeide 2006; de Vries 1956-1957 II, pp.116-120), where Óðinn was at the top of the pantheon and received these epithets (de Vries 1956-1957 II, pp.84, cf. pp.38-39).

${ }^{12}$ Krohn 1906, p.164; Holmberg [Harva] 1915, pp.67-70; Mühlenbach, Endzelīn 1923-1932 II, p.627; Loorits 1932, pp.109-111; 1949-1957 II, pp.22-23; de Vries 1956-1957 II, pp.113-115, 124-127; Haavio 1967, p.332; Biezais 1972, pp.111-115; Laurinkiené 1996, pp.17-19; Siikala 2002a, p.204; Bertell 2003, pp.73-81; West 2007, pp.251255. The poorly attested Livonian tradition appears to parallel the Latvian (Loorits 1926, p.56), including the identification of Pikne with the smith of heaven (Loorits 1926, pp.51-52; cf. Biezais 1972, pp.105-106; cf. also Salo 1990; 2006). Cf. also Thompson's (1955-1958) motifs A157.1 ('Thunderweapon'), A157.7 ('Hammer of thunder god'). nificant for approaching ATU $1148 \mathrm{~b}$ because - with the exception of Estonian traditions - it presents a conception of the source of thunder as a musical instrument or other device which does not otherwise emerge as a conventional attribute of the thunder-god or conventional aetiology of thunder (neither synchronically nor historically).

\section{The nature of the survey}

Studies on systems of relationships among thundertraditions in the Circum-Baltic tend to focus on traditions in only two or three Circum-Baltic cultures. This has been conditioned by the history of scholarship for each tradition, scholarship which can never completely sever its roots in arguments over whose culture has been borrowed from whom - arguments heated by Romanticism and slick with the sweat of nationalism. ${ }^{13}$ A central factor in the persistence of these attitudes is, however, the language barrier: any comparative study requires knowledge of minimally half a dozen languages, and realistically several more. Had it not been for the generous assistance of Jūrate Šlekonyte with Lithuanian materials, Aldis Putelis with the Latvian example, and Eila Stepanova with one Sámic example (available only in Russian translation), this overview could not have been completed. The language barrier is a serious obstacle in Circum-Baltic comparative research, and it is imperative that the corpora of these diverse traditions are made accessible, much as Daiva Vaitkevičiene (2008) has recently done with the corpus of Lithuanian healing charms.

This survey is organised by linguistic-cultural group. Although the earliest documented evidence is found in medieval Germanic sources, these present certain issues which require addressing them last. The Sámic material will be presented first, approaching the traditions on the east side of the Baltic Sea, moving from north to south. Although ATU 1148b is largely if not completely extinct in the cultures in question, this survey should not be considered completely exhaustive. The diverse evolution of ATU 1148b in different linguistic-cultural groups makes finding relevant materials problematic for two reasons. First, not all examples are readily traceable through archive indices, and some sources may simply not yet have come to light. ${ }^{14}$

\footnotetext{
${ }^{13}$ E.g. studies rooted in schools of Germanic studies tend only to take Baltic cultures into account where etymologies are concerned, even in broad comparative surveys: cf. DuBois 1999, pp.2, 78; Bertell 2003, pp.72, 190-191.

${ }^{14}$ E.g. no index of Sámic materials has been generated (cf. Kecskeméti, Paunonen 1974, p.249, where Charnoluskii 1962, pp.35-40 appears under AT 1148b, but not Itkonen 1931, p.37-47); the archive's index card for SKS KRA Krohn, Kaarle 8261 has been lost or misfiled; additional
} 
Second, evidence of ATU 1148b is diffused across multiple genres (proverbs, belief legends, aetiological legends, ballads, etc.) and may be filed according to the interpretation of the collector without cross-indexing. Nevertheless, additional data is not anticipated to significantly impact the findings of the present survey, except to offer perspective on the Sámic and Latvian examples. This survey is the first stage in a long-term plan for a 'mostly-exhaustive' collection of sources of ATU 1148b with critical text and accompanying English translation.

\section{ATU 1148b among the Sámi}

The Sámic tradition presents the capture and binding of the thunder-god rather than the theft of his instrument. Axel Olrik (1906), followed by Kaarle Krohn (1906), introduced it into discussion for comparison with Germanic materials, and their works became themselves sources for later research (cf. Balys 1939, p.41). Their source was a dictionary of Sámic mythology in Jacob Fellman's (1906) Anteckningar under min vistelse i Lappmarken. The dictionary was purportedly developed from both Sámic and Finnish informants owing to their long history of cultural contact and exchange (Fellman 1906, p.74). The entry 'Atshe, father, Aija, Aijeg, grandfather or grandmother [...]' describes a sacrificial cave on (Inari[?] Sámic) Aijegjavre / (Finnish) Ukonjärvi - 'Old Man's Island' or 'Island of the Thunder-God' - in Lake Inari (northeast Finland), where 'Aijeg' was imprisoned for a time by 'Jeettanas' (Fellman 1906, pp.82-86). A fuller account of the narrative appears under 'jettanas, jeettanas', cannibalistic monsters of insatiable appetite (Fellman 1906, pp.102103). The term jêttanas appears to be a Germanic loan (cf. Old Norse jotunn, Modern Swedish jätte), and the description resonates strikingly with the term's etymology, which connects them to 'eating' (Harris 2009, pp.488-493; Tolley 2009, pp.232-238).

In this narrative, the capture and binding of the thunder-god 'Termes' (sic) in a cave is not elaborated. The majority of the text is concerned with the resulting drought and the harm it caused to men and animals. Two sayings are included for which the narrative

Finno-Karelian material may be sitting in audio archives, as yet untranscribed and unindexed; LFK $765 / 587$ (in Balys 1939, p.36) is not listed under AT 1148b (cf. Arājas, Medne 1977) and according to Aldis Putelis, the last item in this collection to be properly indexed was, oddly enough, LFK 765/586; no Lithuanian examples are presently indexed under AT 1148b (cf. seven printed in Balys 1939, pp.34-36); large quantities of Sámic and Finnic materials are preserved in archives of the former USSR where they are filed and indexed by collector rather than by item type or typology. supplies an explanation: Termes läi tshadnum gidda ('Termes was bound fast'); Pajan läi tshadnum gidda ('Thunder was bound fast'). The jêttanas are suspected because drought was in their interest (?!). While they sleep, the servant of Termes sneaks in and frees the god, who ascends into the sky and generates seven weeks of rain to wash out the jêttanas. The rain and storm is in no way related to an instrument.

Two additional versions of the narrative imply that its significance waned sufficiently for it to be subordinated as a resource in other narrative frameworks (cf. Frog 2010, pp.88-102). ${ }^{15}$ A narrative recorded in Skolt Sámi in Norway, north of Finland, in 1927 or 1929, opens with the statement that a devil (tsuartt) once (literally 'some times') bound 'Tiermas' (Itkonen 1931, pp.37-47). The example has no concern for rain or a conflict between the thunder-god and the devil: a man who is the servant of the devil is the protagonist, and he is given keys but forbidden to enter a single chamber (cf. ATU 312). Tiermes is bound in that chamber and liberated by the servant while the devil sleeps. The man remains the protagonist and rides on Tiermes’s back in a Magic Flight sequence (ATU 313), in which Tiermes functions as a magic helper. A variant published in Russian by V. V. Charnoluskii (1962, pp.35-40) presents the same pattern except that the devil appears as a cannibalistic bear; the captured god is simply named 'Thunder' ${ }^{16}$ and locked in a forbidden storehouse, while the protagonist is a maiden, kidnapped by the bear, who also escapes in a Magic Flight on the god's shoulders once she frees him. On reaching her home, he states that he will return to marry her when she comes of age and they will fly through the sky and herd clouds. ${ }^{17}$

${ }^{15}$ This presupposes that the preceding local/regional/ (potentially) Inari Sámic example was relevant to the Skolt Sámic tradition; cf. relationships of Finnish and Karelian (§4) and Estonian and Setu traditions (§5).

${ }^{16}$ This is consistent with variation in naming in other traditions, but it could potentially be attributable to the translator.

17 I am thankful to Maths Bertell (p.c.) for pointing out that Erich Johan Jessen-Schardebøll (1767, p.20) describes how (South[?]) Sámi shamans would 'free' 'Horagalles' with yoiking, drumming and sacrifice. Although the motif of 'freeing' the god may be traditional and related to ATU $1148 \mathrm{~b}$, the motif of capture is absent: 'freeing' the god is equivalent to sending him on a mission as a shamanic helping spirit, and the account is concerned with actual ritual practice (or narratives thereof) rather than a myth, legend or tale about the god. Jessen-Schardebøll comments that if Horagalles is unable (!) to harm the adversary that he is sent against, he will return and turn on the shaman who 'freed' him. (Jessen-Schardebøll 1767, p.20.) This seems less in character for the god than a helping spirit (cf. the god's role as a magic helper in the narratives above). This account seems to support that Sámic beliefs carried a conception that the thunder-god was 'set free'. It also offers

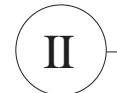

BALTIC WORLDVIEW: FROM MYTHOLOGY TO FOLKLORE 


\section{ATU 1148b among Finno-Karelians}

The Finno-Karelian corpus consists of eleven narrative accounts. The examples were collected in a band crossing Finland into Russian (Ladoga) Karelia from east to west. Two were collected in North Ostrobothnia in 1883 (Balys 1939, pp.38-39). Eight were collected by Kaarle Krohn in 1884 and 1885 (Balys 1939, pp.39-40), presumably because the two earliest examples took his interest and he began explicitly requesting related material wherever he happened to be doing field work. A final, exceptional variant was collected in 1935: ${ }^{18}$ the basic Finno-Karelian ATU 1148b schema had been adapted to a conventional aetiology of thunder from Elijah's wagon, ${ }^{19}$ and the theft of the god's wagon is presented as an aetiology of the hostility of thunder toward devils. It is clear that the narrative was not prominent in the era of collection and had to be actively sought: one account consists of only a few phrases; two others mention memory failing the informant.

The jyristimet ('objects which thunder') are normally not described: in one case these are clearly disk-shaped stones; in another it is a kone ('machine'). Only two examples present the circumstances of the theft - while the thunder-god sleeps - and three examples fail to mention the theft entirely. A fear of thunder and associations with rain are rare; only two examples mention hiding the object and locking it in a room. The thunder-god assumes a disguise and becomes the devil's servant. They go fishing and the god displays one or more feats of strength. These take the form of using a tree as a beater or rowing with such strength that the boat breaks in half and the devil must swim to shore. The first of these displays of strength is otherwise encountered in the mythological poetic narrative tradition (cf. Krohn 1928, pp.35-38; 1931, p.126). The second is found in variants of ATU 1087, The Rowing Contest, which Uther (2004 II, p.32) lists only in Finnish, Sámic and Scandinavian Germanic traditions. Finno-Karelian ATU 1087 variants fall more or less evenly into two groups: a) combinations with ATU 1148b; b) a comic series of a mortal hero's adventures (or independent adventure) as a servant of a devil, indexed as a series of tale-types. ${ }^{20}$ It seems likely that the latter are adaptations subordinating the episode to

a connection between Sámic ATU 1148b and magical practice, but this could be a mistake, misunderstanding or conscious (ideological) misrepresentation of the tradition.

${ }^{18}$ SKS KRA Pulkkinen, Hannes KRK 113, p.197.

${ }^{19}$ SKS KRA Syntytaru card catalogue, group Maailmansynty, sub-group Ukkosenjyrinä, where SKS KRA Pulkkinen, Hannes KRK 113, p.197 is cross-indexed.

${ }^{20}$ E.g. SKS KRA Taipale, Matti 3, p.6, 1859: AT $1005+$ $1012+1006+1115+1116+1087+\ll ? »+1063+1091+$ $1092+\ll ? »+1130$. a new narrative framework as ATU 1148b dropped out of cultural activity (cf. Frog 2010, p.88). The recovery of the instrument exhibits a wide range of variation. The majority express the devil's inability to play the instrument, while the god's playing is characterised by a gradual increase in volume. The narrative climaxes with the devil (and his children, if mentioned) collapsing or being destroyed and may include the destruction of the devil's house.

The Finno-Karelian narratives all exhibit extremely narrow fields of emphasis and concern, normally with one strength test (which leaves the devil looking foolish) and the playing of the thunder-instrument (which may be no more than a strength test). How or why a devil came into possession of the thunder-instrument does not seem to have interested informants. There is rarely any indication of a connection between the instrument and weather or between this narrative and more general patterns of hostility between thunder and devils.

\section{ATU 1148b among Estonians and Setus}

The richest corpus of ATU 1148b, both in terms of the number of examples and the length and complexity of their manifestations, was documented in Estonia. Oskar Loorits (1932, p.95) stresses that there are remarkably few variants considering the interest of collectors: 25 items (including Setu examples) are identified as ATU 1148b. This corpus is also the most accessible: German translations of 24 examples appear in Loorits (1932) and Anderson (1939). These scholars reduce the corpus to 20 basic examples, with five examples exhibiting dependence on a written exemplar. The Orthodox Setu of southeast Estonia (often treated as Estonian) maintained distinct forms of the narrative, identifying the thunder-god with Ilja ('Elijah'). Additional material (not identified as ATU 1148b) demonstrates the cultural activity of the narrative through its reflection in other genres. A legend recorded in Rõuge (Võrumaa, southern Estonia) claims a devil was witnessed fleeing from the thunder-god with a stolen piibar ('flute'), which the god immediately recovered (Loorits 19491957 II, pp.23-24). Variation (or perhaps fixity) in the conception of the thunder-instrument - normally pill ('instrument') (§1) (Loorits 1932, pp.109-111), allowing it to remain unresolved in the social transmission - may have been more common in southern Estonia (Võrumaa and Setumaa). Estonian tradition exhibits consistent conceptions of this as a blown instrument. According to Loorits (1949-1957 II, pp.26-27), the god's instrument is only presented as a drum in variants of ATU 1165, where it reflects the Swedish or 
Germanic 'Drum-Beater' Thórr (see §9), and in 'Die Donnertrommel' ('The Thunder-Drum'), an anonymous text published in das Inland (1858), the earliest preserved example of Estonian ATU 1148b, where German trommel may be a translation interpreting the ambiguous pill, particularly considering that a 'drum' does not necessarily accord with the description of the devil's attempt to play the instrument in the text.

Loorits shows that 'Die Donnertrommel' is a German translation or adaptation of an item presented to the Learned Estonian Society by Johann Lagos in 1835 (Loorits 1932, pp.50-51), most probably already influenced by Lagos's conceptions of an ideal Estonian mythology (Loorits 1932, pp.102-108). If Loorits is correct, the original was provided to Friedrich Reinhold Kreutzwald (with whom Lagos worked closely) for his publications of Estonian folklore, and subsequently disappeared. Kreutzwald published two versions of ATU 1148b in 1866. One, developed from this text, was two and a half times the length of 'Die Donnertrommel' (Kreutzwald 1866, pp.123-126): the expansion and variations are generally attributed to Kreutzwald's invention. The other was a very different version in the same collection (Kreutzwald 1866, pp.118-122). No sources for either survive. ${ }^{21}$

Kreutzwald's publication circulated widely and influenced the oral traditions. It is uncertain where his publications introduced ATU 1148b into a community and where these publications may have augmented or reshaped vernacular traditions. U. Masing (1977, p.118) was right to question whether any later documented versions of the narrative were completely free of influence from Kreutzwald's texts. This issue was augmented by early scholarship (Loorits 1932, de Vries 1933, Anderson 1939) which was not well equipped to deal with these problems when approaching the corpus - e.g. regional patterns in 'corrupt' or 'plagiarised' variants stood completely outside their field of vision; correspondences between variants which cannot be attributed to Kreutzwald's texts were overlooked as superfluous. It must be emphasised that there is a tremendous difference between the published texts introducing ATU 1148b into oral circulation (or simply providing informants with sufficient familiarity to present a summary in response to a collector's direct question) and the published texts interacting with conventional traditions already established in circulating discourse. In the latter case, the publication may have augmented an existing tradition, introducing complementary and alternative motifs, sequential arrangements and interpretations or meanings, or it may have done little more than assert the tradition's

\footnotetext{
${ }^{21}$ Walter Anderson (1939, pp.17-27) proposed that the second version was entirely the invention of Kreutzwald.
}

value and a particular form or forms, stimulating the tradition as individuals in the communities responded to the concretised narratives in printed form. Estonian and Setu examples of ATU 1148b must be approached with caution and reserve, but it is nonetheless possible to develop a general overview of certain sets of characteristic features.

Devils' fear of thunder or thunder's pursuit of a devil is often mentioned if not emphasised at the beginning of the narrative. The theft is accomplished while the thunder-god sleeps. A number of variants provide the devil with an assistant, raised to the sleeping thunder-god on the devil's neck and who accomplishes the theft. This is combined with setting a louse to bite the god so that he will move his arm or head from the instrument without waking. The scenario is similar to the Germanic myth of the theft of Freyja's necklace by Loki (Jónsson "Vihjálmsson", pp.98-100) and thus suspected to be Kreutzwald's invention (Loorits 1932, pp.100-101; de Vries 1933, p.108; Anderson 1939, pp.19-20). The devil takes the instrument to his realm (the bottom of the sea, Hell) and may specifically lock it away. The thunder-god disguises himself and takes work as a servant, most often with a fisherman (developed or maintained in relation to the Estonian devil's strong predilection for hiding in water). The fishing sequence results in the capture of the devil in the net and gaining an invitation to a wedding which the devil is holding. At the celebration, the devil brings out the pill and he (and perhaps all present) are unable to play it. The fisherman suggests that the disguised thunder-god be allowed to try. The thunder-god plays and destroys all of the devils. One version (in two examples) presents the motif of increasing volume (§4) (cf. Anderson 1939, p.52). In a few variants, the thunder-god asks his companion to get onto his back (cf. §3).

\section{A uniquely Livonian tale}

The Livonians are a Finnic linguistic-cultural group in Latvia whose language is almost extinct. Their traditions were closely related to those of southern Estonia. Information on Livonian thunder traditions is limited, and ATU 1148b is unattested (see Loorits 1926, pp.4956, 252-253). A remote parallel may potentially be found in a popular and well-attested narrative which appears otherwise unique to Livonian tradition. Comparison is practical for discussion rather than any relationship being demonstrable. The narrative describes a fisherman and his companion fishing, of whom (as in ATU 1148b) only one observes a mythic being (not the devil). The being invites him to an undersea wedding where he (rather than the thunder-god) serves as a musician. (Loorits 1926, pp.143-163, 261-262; 1949-

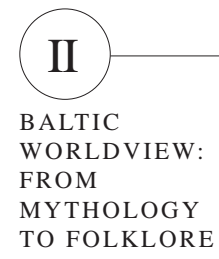

TO FOLKLORE 
1957 II, pp.249-252; III, p.342.) This tale exhibits correspondences in narrative pattern and motif-systems to Estonian ATU 1148b without the thunder-god and conflict over the instrument. ${ }^{22}$ If it were more widely known, this tradition could have provided material which was synthesised into the fisherman-companion of Estonian ATU 1148b. However, if the parallels are not merely typological, the system of narrative material from ATU1148b may have been radically revised into a new narrative where the subordinate figure became the protagonist, as in Sámic examples (§3).

\section{ATU 1148b among Latvians}

Only one Latvian variant of ATU 1148b has been identified (LFK 765/587; Balys 1939, p.36), which Aldis Putelis has generously helped me to investigate. The example was recorded in the Ilūkste region (southeast Latvia) in 1933 from the collector's mother, who purportedly heard it from her parents. The account says that God laid down his lighter / tinder box and his trumpet and went to sleep. A devil takes these and tries to play them for seven years, during which time there is neither thunder nor lightning in the world. When God wakes up, he has no work without his instruments and takes employment as a shepherd. No employer is mentioned. One day while herding, he notices a passing devil and follows him into a cave where he finds his instruments and all of the devils trying to play them. God asks to try, and the collector (presumably) notes, 'we must assume he looks like a simple shepherd'. There is thunder and lightning, all of the devils flee, and God returns with his instruments to work in the sky.

The pattern of seven years without thunder or lightning generally accords with the Estonian and Setu traditions (§5), where the need to take different employment is also encountered, albeit less often. The instrument is a 'horn' in a variant from Setumaa, where Ilja serves as a shepherd, and conceptions of thunder as a shepherd of clouds are reflected in the legend from Rõuge (Võrumaa). It is noteworthy that there is a congregation of devils rather than just one or one and his family. Balys (1939, p.51) emphasises that this variant presents the thunder-figure as 'God' rather than a secondary figure such as Ilja, but overall it falls in neatly with the Setu material. However, the variant offers no indication of emphasis or significance in the telling, and one variant does not offer insight into the broader Latvian tradition.

\footnotetext{
${ }^{22}$ A fuller discussion of how this narrative tradition relates to and contrasts with other traditions in the Circum-Baltic that associate water-spirits with music and musicians playing for supernatural beings is beyond the scope of this article.
}

\section{ATU 1148 b among Lithuanians}

The first five examples of Lithuanian ATU $1148 \mathrm{~b}$ presented by Balys (1939, pp.34-35) were collected by students on questionnaires in 1925 and 1935 in the Marijampole District (southwest Lithuania). One variant collected by students reports that a devil stole Perkūnas's pypkè ('pipe [for smoking]'), and rather than 'thunder', the account claims that anyone who looks at Perkūnas dies. This begins as an aetiology of Perkūnas hunting the devil, then the devil raises a man with a mirror on his back (cf. Kreutzwald's text); the devil dies on seeing Perkūnas, Perkūnas dies on seeing his reflection, and the man goes home. Two examples, collected in different parts of the Vilkaviškis Municipality, report that God quarrelled with Perkūnas and threw him out of heaven, variously because Perkūnas stole God's axe, knife and dviratis ('two-wheeler' [bicycle, chariot]) (1935), or Perkūnas took these (and a goat) when being cast out of heaven (1925): the 'theft' of the thunder-god's attributes (\$1) present an implicit aetiology of their association with Perkūnas while maintaining the basic theft scenario of ATU 1148b. The knife is not an attribute of Perkūnas: it is stolen from him by a devil as an aetiology for why Perkūnas throws his axe at devils. The collection of two versions of this account across ten years implies some type of underlying conventional form which warrants comparison with the apparent reorganisation of ATU 1148b's motifs (cf. §3). A student also collected an aetiology of Perkūnas's hostility toward the devil in an account of a devil stealing an axe (not associated with thunder) shared between Perkūnas and his brother. Balys (1939, p.36) compares this to a local legend about two giants who share one axe, into which the schema of the theft as an aetiology of hostility has been synthesised. The most peculiar of this group is an account in which the devil disguises himself as a beautiful woman, so that when Perkūnas kisses 'her', his lips knit shut; ${ }^{23}$ now as soon as he sees the devil, 'he immediately opens his mouth, and the roar which is released is called thunder' (Balys 1939, p.34). It is unclear whether this should be identified with ATU 1148b or is an unrelated aetiology of thunder. Balys (1939, p.35) presents two additional Lithuanian examples. One, collected in central Lithuania in 1935, presents an aetiology of the Pleiades in an account of a sieve, hung in the sky by the Virgin Mary, stolen by the devil and recovered by Perkūnas. The other, collected in northeast Lithuania in 1935, is another aetiology of hostility, owing to the theft of a stone intended for Perkūnas's house. Of the examples presented by Balys, six appear to be evidence of ATU

\footnotetext{
${ }^{23} \mathrm{Cf}$. the Thórr-myth involving his wife and an aetiology of his hammer in which Loki's lips are sewn shut (Faulkes 1998, p.41-43).
} 
$1148 \mathrm{~b}$ traditions. Four present thefts of a thunderweapon object (axe, stone), but in the two examples where the axe is identified as a weapon, the devil steals another object.

Jūratė Šlekonytė found four additional narratives not listed by Balys catalogued as belief legends (Kerbelytė 1999-2002 III, p.178) and one as an aetiological legend (Kerbelyte 1999-2002 III, p.21). Three of these describe a devil refusing to return money borrowed from Perkūnas, ${ }^{24}$ which may be the result of interference from Lithuanian ATU 1165 (§9). The fourth is the only variant which mentions that Perkūnas was asleep when a devil stole his guns/bullets, ${ }^{25}$ clearly identifiable as the thunder weapon (Vèlius 1987, p.131; Laurinkiene 1996, pp.18-19). The aetiological legend states that the devil stole Elijošius's ('Elijah's') and Einokas's ('Hananja's') axe, chisel and hammer, explaining that when Elijošius travels, it thunders. ${ }^{26}$

\section{Preliminary overview: from Lapland to Lithuania}

The motif of sleep during the theft is reflected to varying degrees in all ATU 1148b traditions. The god appears immediately aware of the identity of the thief, otherwise encountering the adversary/instrument is accidental. From Finland to Latvia, the theft is followed by a period of disguise in which the god takes employment of low status, working for the devil (§4), or for the figure invited to the devil's celebration $(\$ 5)$, or without specification $(\S 7)$. The Finnic traditions (§45 ; cf. §6) associate service with a fishing adventure. Finnic traditions and the Latvian example present an inability of the devil or community of devils to play the instrument, which is then unwittingly provided to the thunder-god who plays it effectively. Playing the instrument incapacitates, destroys or drives off the devil and the devil's community. Fundamental to this narrative is an underlying conception of a) the thunderinstrument as an object which a devil can obtain, but b) not get to function properly; the instrument can also c) be presented to the disguised thunder-god as though d) appropriate use or playing is not in itself dangerous and may even be positive and desirable. Conceptions of thunder and attributes of the thunder-god (§1) must therefore be considered a factor in the cultural activity of ATU 1148b.

Estonian and Setu traditions ( $(5)$ appear to be the most vital: they are the most well-attested in the number of examples, the examples are generally longer and more

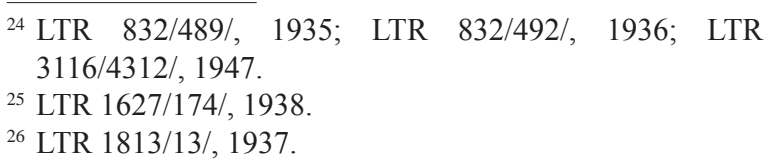

complex narratives, and they clearly participate in the communication and maintenance of aspects of the conceptual system and belief traditions to which they are connected (cf. §7). This includes the correlation between the thunder-instrument and rain (or its absence), which maintained currency, and also the relationship of thunder and devils. The latter included devils' fear of thunder and the power of thunder to overcome or drive away devils. ${ }^{27}$ In contrast, Finno-Karelian examples (§4) are few, short, and simpler narratives, almost all of which are preserved owing to the work of one enthusiastic collector. However, the Finno-Karelian examples are relatively widespread and the short, simple form was consistent and clearly conventional. The only explicit aetiological use is in the unusual example in which ATU 1148b was mapped over the widespread aetiology of thunder from God's wagon. Other examples express the power of thunder to overcome or destroy the devil, but fear is merely characteristic of the 'stupid devil' who is intimidated by feats of physical strength. Finno-Karelian ATU 1148b appears to have become dislocated from conventional conceptions about the aetiology of thunder. Although ATU 1148b is one of many Circum-Baltic narratives about thunder and the devil $(\S 1)$, and it both affirms the power and significance of thunder as well as the inferiority and stupidity of devils, it is not connected to the hostility between thunder and the devil (which otherwise both emerges in and as aetiological legends): the Finno-Karelian ATU 1148b tradition appears primarily oriented toward humour and entertainment (cf. Frog 2010, pp.235-236).

Each Finnic tradition exhibits culturally specific social patterns in how ATU 1148b was used and of its significance in society: they reflect shared sets of conventions in its cultural activity per linguistic-cultural group. Insofar as these shared sets of conventions can be considered inherited through processes of social communication, it is reasonable to suggest that social patterns of use shaped the narrative's evolution as an historical process - i.e. that patterns of social conventions are not arbitrary within a culture but rather they are conditioned by the history of conventional applications, and as innovations, deletions and strategies in application become socially established as conventional, they become part of that historical process.

The evolution of the tradition can be considered according to scales of probability through correlations of social patterns of use, relationships to other material in the tradition ecology and in the broader conceptual system, and to the corresponding traditions in

${ }^{27}$ On hunting or chasing as a motif in this context, see Vèlius 1987, pp.126-139; Ajkhenvald et al. 1989, p.158; Laurinkiené 1996, p.23; Valk 1996.

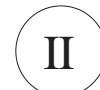

BALTIC WORLDVIEW: FROM MYTHOLOGY TO FOLKLORE 
other cultures. This does not mean that questions can be simply and readily resolved. Comparison of FinnoKarelian (§4) and Estonian/Setu ( $(5)$ traditions implies that either: a) the Estonian/Setu tradition underwent an accumulation of information as a consequence of interest in and the significance of the narrative, expanding the thunder-god's service to the devil and the fishing adventure through the introduction of the fisherman who is invited to a wedding (cf. §6); or b) the FinnoKarelian tradition underwent a loss of information as a consequence of dislocation from belief traditions and increased emphasis on adventure and humour, reducing the devil and the fisherman with whom the thunder-god enters service to a single figure and consequently eliminating the celebration in the devil's home as grounds for inviting guests (see §11.4, §12). ${ }^{28}$ Comparison of only these two traditions cannot resolve which is more probable.

Lithuanian sources (§8) are, for the most part, highly problematic. Nonetheless, they reveal that there was a tradition of the theft. They also reveal that in the culture where the thunder-god hunting devils was most pronounced, the tradition of the theft maintained conventional value as a social resource for the aetiology of Perkūnas's hostility. Comparison with other CircumBaltic traditions presents a high probability that Lithuanian ATU 1148b underwent a tremendous loss of information: the narrative is reduced to the schema of the theft, 'losing' the identification of the stolen object with the god's loss of the sound or power of thunder, as well as 'losing' narrative material dependent on that identification (i.e. everything which follows on the initial episode). ${ }^{29}$ This loss of information appears directly related to variation in the object stolen (knife, wood axe, tools, building stone, pipe, unreturned money) and the emphasis on the act of theft as the aetiology of hostility and pursuit. This contrasts sharply with the development of ATU 1148b in Sámic traditions where no theft appears. Sámic examples place emphasis on the relationship between the god and rain, and the god who embodies that power (rather than an attributed instrument) is locked away, apparently in a loss of information synthesising motifs associated with the theft and recovery into a single episode. ${ }^{30}$ The Sámic tradition exhibits different priorities, such as the maintenance of a god-rain relation rather than a god-devil rela-

${ }^{28}$ On accumulation and loss of information, see Frog (2010, pp.119-121, 178-179, 190-191, 310, 314-315).

${ }^{29}$ See also Vèlius (1987, pp.127-128) for an overview of aetiologies of hostility and other associations of the devil with a 'theft'.

${ }^{30}$ There is also a possibility that the Sámic tradition reflects a synthesis of ATU 1148b traditions with an established tradition of the captured thunder-god (cf. Anderson 1939, p.72n). tion, and developments related to emphasis on different ATU 1148b episodes (theft versus recovery). More strikingly, synthesis with the Magic Flight presents the liberated god fleeing from the devil rather than pursuing him. This is a Sámic development in the evolution of ATU 1148b which does not seem like it could be possible in Lithuania, where Perkūnas's hostility and pursuit of the devil appears more central than his association with thunder or rain. Sámic and Lithuanian examples both reveal the maintenance of indexically associated systems of motifs mapped over new objects and adapted to new contexts. The evolution of each appears conditioned by the broader tradition ecology and conceptual system in which it participates. I propose that there is a correlation in the cultural milieu between social patterns of use and broader conceptions of the thunder-god and the aetiology of thunder, and that these impact the evolution of the narrative tradition.

The loss of information does not mean that the narrative material simply ceased to exist. Linda Dégh (1995, pp.97, 125-127, 218-219) emphasises that compelling narrative elements continue to be adapted to new contexts and applications even when the narratives or genres with which they are associated move toward extinction (cf. Frog 2010, pp.72-102). Although the recovery of the thunder-instrument is not exhibited in Lithuanian ATU 1148b, the thunder-god shows up as a musician at a different wedding - in ATU 1165, 'The Troll and the Baptism', a popular Circum-Baltic narrative. ${ }^{31}$ ATU 1165 commonly represents a man required to invite a troll or devil to his child's baptism; the man dissuades the devil's attendance by mentioning mythic figures in attendance, culminating in 'Drum-Beater' (the thunder-god / Thórr), in response to which the devil declines the invitation (cf. Balys 1939, p.158; Vèlius 1987, p.131), often mentioning a past injury. Lithuanian and Latvian ATU 1165 clearly follow the common pattern, one example even mentioning the drum (Balys 1939, pp.140-141), but the celebration is a man's wedding; a devil has loaned money to the groom (cf. §8); and the devil flees the wedding because the thunder-god is present as a musician (Laurinkiene 1996, p.23; for variants, see Balys 1939, pp.137-161). This unusual form of ATU 1165 could be related to a synthesis of narrative material associated at some earlier period with the recovery of the thunder-instrument, much as examples of Lithuanian ATU 1148b (§8) appear fused with other material. This potential reuse of narrative material is interesting for comparison with the Livonian tale of a fisherman attending a wedding as a musician (§6), as another potential example of an episode finding renewed social value.

\footnotetext{
${ }^{31}$ Balys 1939, pp.137-161, 213-216; Uther 2004 II, pp.5758; cf. Barag et al. 1979, p.270.
} 


\section{The Greek analogue of Nonnos}

The only clear example of ATU 1148b outside of the Circum-Baltic cultural area is the Greek myth of Zeus and his great opponent Typhoeus in the Dionysica of Nonnos of Panopolis, composed in the fifth century A.D. ${ }^{32}$ Nonnos combines ATU 1148b with a corresponding myth about the theft of Zeus's sinews, attested elsewhere. These have been discussed in detail by Uku Masing (1944; cf. Masing 1977, pp.124-129) and William Hansen (1995; 2002, pp.305-314). In Nonnos's poem, Zeus lays aside his lightning in order to go to bed with Plouto ('sleep') and Typhoeus accomplishes the theft (Dionysica I.145-162). The weight of the lightning makes it difficult to wield and it does not resound as it should (I.294-320). Typhoeus then hides the lightning in a cave. Zeus disguises a man as a pipeplaying shepherd. Typhoeus challenges him to a playing match (I.362-480), in which Typhoeus will play the

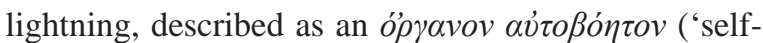
playing instrument') (I.432). This competition does not take place. Nonnos abruptly introduces a parallel tradition about Zeus's stolen sinews: the shepherd claims Zeus burnt away the strings of his seven-stringed lyre ( $\kappa \imath \dot{\alpha} \rho \alpha)$, but that if only he had the sinews of Zeus, he could play a tune that would affect the whole world (I.486-508). Typhoeus provides the sinews, the shepherd conceals them in a rock (they are never mentioned again) and resumes playing his pipes. Meanwhile Zeus recovers the hidden thunder-instrument without conflict (I.507-II.41). The peculiarities of Nonnos's account avoid the competition of playing music in which the thunder-god of ATU 1148b would demonstrate his ability and destroy his adversary (presented as a separate conflict). This analogue provides evidence of the potential age of ATU 1148b, presenting: a) the theft during 'sleep'; b) thunder as a 'self-playing instrument' which nonetheless c) requires strength to play, d) should be played appropriately, and e) cannot be played by the 'devil'; f) hiding the instrument; g) a god-servant relation with h) a disguise as a shepherd; and i) a challenge of playing which results in j) the 'devil' offering the/a stolen power attribute of the god (sinews) k) for a musical instrument l) to play for him as entertainment.

\section{Approaching ATU 1148b in Norse Germanic cultures}

Sources for the Germanic tradition are early, limited, and problematic. Two eddic poems recorded in the 13th century have been central to discussions of Ger-

\footnotetext{
${ }^{32}$ Cited according to Rouse's (1940) edition; on Typhoeus, see West (2007, p.257-258).
}

manic traditions of ATU 1148b. Prymskviða $(D k v)^{33} \mathrm{de}-$ scribes the theft and recovery of Thórr's hammer, and Hymiskviða $(H k v)$ is conventionally treated as an authoritative presentation of Thórr's fishing expedition. Finally, evidence of ATU 1148b reflected in Thórr's adventure to the home of a giant called Geirrøðr will be considered.

\subsection{Prymskviða and ATU 1148b}

$P k v$ is the only versified tradition of ATU $1148 b,{ }^{34}$ with its descendents in later Icelandic rímur poetry and Scandinavian ballads; ${ }^{35}$ there is no evidence of a corresponding prose tradition (cf. Liungman 1961, p.267), and $5 k v$ 's relationship to tradition has been subject to much debate. ${ }^{36} \mathrm{Pkv}$ opens with Thórr waking up to discover that his hammer has disappeared. He sends a subordinate figure (Loki) to search for it, and the thief, a giant called Thrymr, demands the goddess Freyja in exchange for the hammer. Thórr travels with his companion Loki to Thrymr's home for the wedding, with Thórr disguised as the bride and Loki as 'her' handmaiden. Thórr astounds the giant Thrymr with a display of appetite rather than strength, for which Loki offers excuses. Thórr's hammer is brought out and placed in Thórr's lap to consecrate the bride, at which point Thórr uses it to kill everyone.

$\not k v$ exhibits the principle system of ATU 1148b's motifs: theft during sleep, a servant, disguise, infiltrating the household of the adversary/thief, a wedding celebration, feats which impress the host, the thunder-instrument unwittingly given to the god, and the destruction of the adversary with the instrument. There are also noteworthy contrasts; Thórr resists rather than makes the plan and disguise; his thundergod appetite threatens his disguise (as the goddess of sexuality) rather than threatening or impressing the devil; the disguise is not one of service and explicitly humiliates the god. A man assuming a woman's gender role, particularly in sexual relations (an implied con-

${ }_{33}$ All eddic poems are cited according to the Neckel and Kuhn (1963) edition by poem title, stanza number and line number within the stanza, e.g. Pkv 17.3-4 = Drymskviða, lines 3-4 of stanza 17.

${ }^{34}$ Krohn (1922, pp.205-206; 1931, p.126) suggested that the Finno-Karelian tradition may have had an earlier verse form, largely based on an unwarranted assumption that the authoritative form of mythological narratives should be versified. Nonnos represents the tradition in verse, but there is no reason to believe that this reflects a conventionally versified narrative tradition for ATU $1148 \mathrm{~b}$.

35 On the later traditions, see Grundtvig 1853, p.1-7; Bugge, Moe 1887; Jónsson 1905-1912, pp.278-289; Nielsen 1911; Liestøl 1970, pp.15-18; Bertell 2003, pp.53-61.

${ }^{36}$ See de Vries 1928; Hallberg 1954; Jakobsen 1984; Magerøy 1991 (1956); von See et al. 1997, pp.509-575; McKinnell 2001; Bertell 2003, pp.53-61; Thorvaldsen 2008; Frog 2010, pp.213-216.

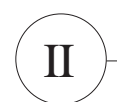

BALTIC WORLDVIEW: FROM MYTHOLOGY TO FOLKLORE 
sequence of the wedding) was the highest possible offence in early Norse culture (Meulengracht Sørensen 1983). In $P k v$, Freyja states that the proposed union would be offensive to her because of implications of excessive female sexual appetite ( $\not k v 13)$. This establishes the offensive quality of the role which Thórr is compelled to fill in his disguise, concerning which he objects: 'Mic muno cesir / argan kalla // ef ec bindaz læet / brúðar líni’ (Pkv 17.3-6) - the offensive sense of which is roughly equivalent to modern English 'The gods will say I was out to get $\mathrm{f}^{* * *}$ ed up the arse if I let them do me up in a wedding dress'. Where Freyja's objection succeeded, Thórr's fails. Thórr's initial attempt to trade Freyja for his hammer is contrary to his role as defender of the gods' realm and their women from giants (Clunies Ross 1994). Moreover, he fails to give the goddess to those he should protect her from, and he is subjected to the role which she rejected. Thórr's appearance in a wedding dress is contrasted with the storm raised by his goats and chariot on his journey to meet Thrymr ( $\not k v 21)$, his appetite ( $\$ k v$ 24-26), and the furious blazing of his eyes when Thrymr tries to kiss him ( $P k v$ 27-28). The phallic farce of castration through losing his hammer while he slept (which Margaret Clunies Ross [2002, p.188] suggests would have been understood in terms of homosexual rape) comes to a climax when the hammer is placed in the lap of the emasculated Thórr-bride, and he rejoices at the return of what is his, using it on everyone ( $P k v 30-31$; Clunies Ross 2002, pp.188-189).

$\not k v$ is purely concerned with the adventure of the hammer's recovery by Thórr and Loki: Thrymr does not threaten the gods, their domain, and there is no indication that he would otherwise take Freyja by force; there is no mention of Thórr's hammer as an object which the giants feel in any way threatened by, nor that they are intimidated by thunder (the chariot splits cliffs with thunder and lightning), and there is no indication that the hammer was associated with thunder or rain at all. The priority of presentation appears to be on making Thórr look foolish, humiliating him through gender transgression. Although individual motifs of $\not k v$ are traditional, there is no support in early sources for the narrative as a whole, the name of the adversary, nor for individual mythic events depicted (for example, the bursting of Freyja's necklace, Thórr borrowing it, or any association of Thórr's hammer with brides). ${ }^{37}$ A number of features of $P k v$ as a composition

\footnotetext{
${ }^{37}$ Thórr's remark about what the gods will say about him makes it seem remarkable that the event is never referred to in insult exchanges with other gods (Lokasenna, Hárbarðsljóð). The placement of the phallic hammer in the bride's lap would very possibly threaten her sexuality or nullify the hammer's masculine power (Itkonen 1946, pp.212-213; Salo 2006, pp.38-41), which in this case turns
}

are unconventional, and moreover unconventional in ways that associate the composition with later traditions of poetic narrative. ${ }^{38}$ The lack of evidence for the $b k v$ narrative in early sources contrasts sharply with its later translation and persistence in those later poetic traditions - Icelandic rímur poetry and Scandinavia ballads - where it exhibits no connection to belief traditions. Among rímur, this is one of three preserved 'mythological' narratives, the others being Lokrur (Jónsson 1905-1912, pp.290-310), adapted directly from Snorri Sturluson's parodic account of Thórr's visit to Útgarða-Loki (Jónsson 1905-1912, p.290), and Skíðaríma (Jónsson 1905-1912, pp.10-42), a beggar's comic Christian visionary journey to Valhalla. The corresponding ballads were recorded in Norway, Denmark, Sweden and the Færoe Isles into the 19th and 20th century. This distribution is more remarkable because it is the only known Scandinavian ballad based on a 'pagan' mythological narrative (Liestøl 1970, p.18). Features of $D k v$ 's composition associate it with changes taking place in the poetic tradition across the 13th to the 15th centuries while the narrative, for which there is no early evidence, thrived in the later Christian cultural milieu.

\subsection{Thórr's fishing expedition and ATU 1148b}

In contrast to $P k v$, Thórr's adventure of fishing for the world serpent exhibits tremendous early populari-

the bride into an angry man who kills the groom. The tendency to identify any reference to a hammer or axe in any way connected to a wedding with $p k v$ (e.g. ATU 1165; Motz 1997, p.335) requires comprehensive reassessment, particularly considering that the examples derive not from Iceland, but primarily from Sweden, the function of the instrument may not be bound to weddings per se, or even strictly associated with the thunder-god (Lindow 1994, p.490; Siikala 2002a, p.293), a possibility which becomes still more prominent when the motif is framed in a CircumBaltic context (§1).

${ }^{38}$ E.g. $P k v$ exhibits limited end-rhyme (avoided in eddic verse), over-alliteration (cf. Aðalsteinsson 2009), and uses of parallelism and repetition more characteristic of later rímur poetry and ballads; parallelism includes the use of terms for the two classes of gods (Esir and Vanir) as mutually equivalent in parallel lines ( $P k v$ 15.1-4) and apparently also the placement of Thórr's hammer to bless the bride with the blessing (vígja) by the hands of the mysterious (alliterating) goddess Vár ( $P k v$ 30.5-8) inconsistent with eddic poetry but consistent with rímur; correlations in the verbal text and motif-constellations of $\not k v$ with other poems are uncharacteristic of eddic poetry and appear intended to generate intertextual references for contrast after the manner of parody rather than summary or conventional uses of common poetic themes; these correlations coupled with over-use of archaic-sounding expletive particles (Fidjestøl 1999, pp.207-230) would be consistent with a strategy to 'sound' eddic in the generation of parody (cf. Fidjestøl 1999, p.228). 
ty. ${ }^{39}$ Thórr disguises himself as a youth and enters the household of the giant Hymir. In Hkv, this visit is motivated by the acquisition of a mythic cauldron rather than the thunder-instrument. Hkv is uniquely connected to another poem, Lokasenna, in manuscript prose (Neckel, Kuhn 1962, p.96): it precedes the drinking feast of the giant Ægir, lord of the sea, for which Thórr fetched the brewing-kettle - although Lokasenna presents Thórr arriving after the feast has begun. In Hkv, Thórr enters the household of the giant through association with a companion and is subject to a series of strength-tests. The final strength test is moving the cauldron: Thórr's companion attempts twice and fails; Thórr succeeds and the accomplishment is identified with a ringing noise (Hkv 34). Among the strength tests is the fishing expedition, from which the companion (not attested in any other source) is absent and only Thórr and the fisherman-giant participate. In the prose account of Snorri Sturluson, Thórr makes this visit to Hymir alone, the challenges in the hall are absent, and the motivation for the adventure is awkwardly linked to the preceding narrative, which describes a celebration in Útgarða-Loki’s hall (Faulkes 1982, pp.42-45) (§11.4). The rowing challenge (ATU 1087) is associated with this fishing expedition, but rather than breaking the boat through strength of rowing (\$4), Thórr's foot or feet go through the bottom of the boat in raising the serpent (Meulengracht Sørensen 2001 [1986], pp.63-64).

\subsection{Visiting Geirrøðr and ATU 1148b}

Thórr's visit to the giant Geirrøðr was also popular (Mogk 1924; Simek 1986; McKinnell 1994, pp.57-86). The instigating event is uncertain, but Thórr makes a dangerous journey with a companion and without his hammer; he engages in a series of games or strengthtests in the giant Geirrøðr's hall, concluding with slaying the giant (and everyone else). In the earliest example, the allusive skaldic poem Dórsdrápa (ca. 1000 A.D.), Thórr is mysteriously in possession of his hammer at the conclusion of the adventure (Faulkes 1998, pp.29-30). Alfred Vestlund (1911, pp.109-112) and Jan de Vries (1933, pp.64-65) argue that this adventure concerned the recovery of Thórr's hammer, although the aetiology of the hammer has also been proposed (Jackson 2005, pp.495-496; cf. Faulkes 1998, p.42). Examples emphasise Thórr's strength and power without clear reference to either rain or 'thunder', ${ }^{40}$ al-

\footnotetext{
39 See Meulengracht Sørensen (2001 [1986]); on the early loan into Finno-Karelian, see Setälä (1932).

40 The poem Dórsdrápa is so allusive that it is ambiguous. Saxo Grammaticus presents this myth in his Gesta Danorum ('History of the Danes') as a sort of guided tour of Geirrøðr's hall by human adventurers (tourists) long after the battle. Saxo states that Thórr destroyed Geirrøðr's
}

though the fear of the giant may be present within the conflict.

Thórr does not appear to make this journey in disguise. However, in a later (15th century) euhemerised account, Thorsteinn bæjarmagn ('Thórr-Stone MansionMight') enters the hall of Geirrøðr as the invisible companion of a giant, who, with his entourage, has been invited to a celebration. Thorsteinn lends invisible aid to his companion in the series of strength tests until he is revealed as the servant of this giant. His companion gives him as a gift to Geirrøðr (allowing Thorsteinn's companion to depart safely), who wishes to see a display of the Thorsteinn's ability. (Jónsson, Vihjálmsson 1943-1944 III, pp.405-412.) Thorsteinn has a magical stone (hallr) of three colours with an accompanying metal spike (broddr); when the different colours of the stone are pricked with the spike, different varieties of weather are produced; ${ }^{41}$ the parts will hit anything they are thrown at and return to Thorsteinn's hand (Jónsson, Vihjálmsson 1943-1944 III, pp.400402). Jacqueline Simpson (1966, pp.5-8) has discussed this peculiar object in relation to corresponding objects called 'Thor's hammers' in later Icelandic tradition: these were used in magic by pricking the hammer with its accompanying spike. Thorsteinn refers to the product of this object as leikinn ('playing' [either a game or musical instrument]). Geirrøðr is entertained and encourages Thorsteinn to generate different weather until Thorsteinn performs something called svipuleikr ('whip-play', perhaps 'whip-song' [cf. Cleasby, Vigfússon 1896, p.611]). This throws fire and sparks in the eyes of Geirrøðr, who laughs and asks for more. Thorsteinn gradually increases his playing and concludes by throwing the two parts of his object into the eyes of Geirrøðr and fleeing, the object's parts returning to him thereafter. (Jónsson, Vihjálmsson 1943-1944 III, pp.412-413.)

\subsection{Overview: ATU 1148b in \\ Norse Germanic cultures}

Thorsteinn bæjarmagn is attributed with a weatherproducing object in two parts, comparable to the (always plural) Finno-Karilian jyristimet (§4). Like the thunder-god of ATU 1148b, he enters the hall of the giant in a deceptive manner, presenting himself as a servant although he orchestrates the action. The giant expects entertainment without the possibility of harm when the two-part object is used in a performative ac-

daughters with fulmina ('lightning bolts') (Olrik, Ræder 1931, p.243). Saxo's handling of material is so free that it is unclear whether this reflects tradition, invention, or an interpretation of Thórr's weapon or power as a fulmensymbol for the Latin text.

${ }^{41}$ This is exceptional for weather magic (Simpson 1966, p.6).

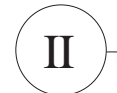

BALTIC WORLDVIEW: FROM MYTHOLOGY TO FOLKLORE 
tion described as 'playing', appropriate to a musical instrument. This performance is accompanied by the motif of gradual increase (§4-5), and Geirrøðr appreciates this performance in spite of its violent products. Thorsteinn throws the two parts at the giant (as Thórr uses his hammer), killing him. The property of these parts to return to the hero is identical to the description of Thórr's hammer (Faulkes 1998, p.42), to which it is somehow equivalent. This increases its probable identification as a thunder-instrument within a motifcomplex and narrative pattern paralleling the recovery episode of ATU 1148b, even though the theft and recovery of the object are absent. This account has been manipulated by the saga author and is clearly intended to be entertaining, but these correspondences make it appear that the material being manipulated included some form of ATU 1148b. This consequently increases the probability that the apparent acquisition of Thórr's hammer after his arrival in the hall in Pórsdrápa (four or five centuries earlier) also reflects some form of ATU 1148b. ${ }^{42}$ However, this does not eliminate the possibility of an aetiology of the hammer, or interaction and variation between ATU 1148b and an aetiology of Thórr's hammer.

$H k v$ presents a narrative which has potentially mapped ATU 1148b over another mythic object held by a giant. John McKinnell (1994, pp.57-86) points out that the 'games' or strength tests in the giant's hall related to acquiring the cauldron appear to follow the same story pattern as in the visit to Geirrøðr's hall. In Hkv, the mythic object acquired is accompanied by a sequence of one figure failing before the god succeeds with a resounding noise. Although a 'disguise' does not generally appear in the visit to Geirrøðr, it was associated with Thórr's fishing expedition. In Hkv, Thórr's fishing expedition is embedded in the story pattern discussed by McKinnell, presenting the possibility that the episode has undergone a (potentially unique) accumulation of information, through which material from an adventure to a giant's hall for the acquisition of a mythic object exhibiting a common pattern with ATU $1148 \mathrm{~b}$ has accumulated around Thórr's adventure with the fisherman.

\footnotetext{
${ }^{42}$ A conventional form of ATU 1148b may be parodied in an episode of the burlesque Bósa saga, where it would have been mapped over a bridal-quest narrative: the stolen object is a princess, the adversary is named Guðmundr (the name of the positive companion in adventures where the adversary is Geirrøðr), the hero and his companion enter the wedding feast in disguise, the hero plays a harp which magically affects people and objects alike, the adversary is struck senseless and the hero escapes with the instrument (in which the princess is concealed, notably for a companion, not for himself) (Jónsson, Vihjálmsson 1943-1944 II, pp.487-491).
}

This accumulation of information may reflect a loss of information from a longer narrative sequence - i.e. if Thórr's adventures in the service of the giant-fisherman was a means of advancing to the home of another giant for the acquisition of the lost thunder-instrument $(\S 5, \S 9)$. The possibility is not unreasonable considering that this basic schema appears in Óðinn's adventure for the acquisition of the Mead of Poetry: Óðinn first engages as a reaper in the service of one giant, gains audience with the possessor of the mead through that association, and eventually accomplishes the theft (Faulkes 1998, pp.4-5). A loss of information could have resulted in the identification of the fisherman with the lord of the hall and a synthesis of distinct narrative sequences. This would parallel the potential loss in Finno-Karelian ATU 1148b (§4) resulting in the god's service with the thief rather than a fisherman (§9).

This possibility is augmented by Snorri Sturluson's connection of Thórr's fishing expedition to his adventures with Útgarða-Loki. Snorri presents these narratives in a fictional dialogue, which the Útgarða-Loki narrative is carefully constructed to reflect and comment on (Lindow 2000). The narrative itself is a burlesque which repeatedly shows Thórr deceived and defeated by his adversaries (see Tolley, forthcoming). McKinnell (1994, pp.57-86) shows that this narrative is developed according to the same story pattern as the visit to Geirrøðr, of which it is the only example where Thórr fails to defeat his adversary. Its reception as a burlesque is emphasised by the direct translation of the written narrative into rímur poetry (§11.1). Snorri’s (unique) connection of the fishing expedition to this narrative is as peculiar and clumsy as the connection of Hkv to Lokasenna: he presents it as a revenge action for the humiliation Thórr suffered in one specific challenge, with the additional jibe that Thórr succeeded in deceiving the (stupid) world serpent with his fishing hook 'no less than Útgarða-Loki had made a mockery of him' with illusions of cosmological proportions (Faulkes 1982, p.44). There is at least the possibility that Snorri connected these two scenarios on the basis of a conventional association. This possibility may find some small support in that both Snorri and Hkv (3738) link this cycle to the myth of the laming of Thórr's goat, which might also be paralleled in the wagon accident on the departure from the Geirrøðr adventure in Book VIII of Saxo Grammaticus's Gesta Danorum (Olrik, Ræder: 1931, p.243). It is possible that these three narratives formed a (variable) system or cycle in which the fishing expedition was associated with ATU 1148b.

All Germanic examples are concerned with actionadventure scenarios, expressions of power, and all engage in varying degrees of humour. It is not clear 
how any of these examples may have related to belief traditions - except possibly $5 k v$, with its orientation toward parody. If Germanic ATU $1148 \mathrm{~b}$ were a system of narratives including the Geirrøor adventure and fishing expedition, there are some noteworthy inconsistencies: a) the companion on the visit to Geirrøðr is never the giant-fisherman, it is normally Thórr's servant; b) Thórr's hammer appears to be absent from the fishing adventure but then is used in the climactic conflict with the world serpent; c) Thórr is disguised for the fishing adventure but (apparently) not for the visit to Geirrøðr; d) only the parody $D k v$ presents the theft during sleep. There is the possibility that ATU $1148 \mathrm{~b}$ had already splintered into separate narratives which had developed conventional forms divorced from the unifying thread of the stolen thunder 'instrument'. Factors involved in this process may have included the interaction of Thórr's fishing expedition with traditions of Christ/God fishing for Leviathan (Gschwantler 1968) and the stimulation of and changes in the cultural activity of Thórr's hammer/axe in response to the parallel cultural activity of the Christian Cross (Capelle 2005).$^{43}$ In other words, the tradition of the fishing expedition may have been subject to radical changes in both form and cultural activity in relation to the rise of Christianity. The splintering of Germanic ATU 1148b would be comparable to its (aetiologically oriented) evolution in Lithuanian (§8). The Geirrøðr adventure (§11.3) may also have developed from ATU 1148b as the latter waned in cultural activity, without ever being associated with the fishing adventure itself. The diversity in the sources (including evidence of a potentially unified theft scenario parodied in $\$ 11.1$ and $\S 11.3)$ persisting in tandem could be a consequence of the majority of sources being documented in Iceland: Iceland was a colony of migrants from across Scandinavia and beyond, who brought their diverse traditions with them - a plurality of conventional forms which may have been as inclined to compete as to synthesise into a unified form (see $§ 13)$.

\section{Perspectives on ATU 1148 b}

The service with the fisherman shared across Finnic and Germanic traditions (§4-5, §11.2, cf. §6) is paralleled by service as a shepherd in Setu, Latvian and the Greek examples (§5, §7, §10). A Sámic example (§3) and the legend from Võrumaa (§5) betray a concept of the thunder-god herding clouds ('service' is not exhibited in Lithuanian examples). It is not possible to make any determination about the significance (or lack

${ }^{43}$ This should not be confused with conscious semiotic 'protest' as has sometimes been done (cf. Nordeide 2006, p.222), although such conscious competitions were no doubt significant in some cases or areas. thereof) in the herdsman versus fisherman disguise/occupation. The Finnic-Germanic isogloss may be partly an illusion following from the paucity of sources and the variant forms of the traditions encountered in more peripheral cultural areas. Nonetheless, Germanic parallels make it more probable that Estonian traditions of the thunder-god's service with a fisherman are related to an early Germanic form. This supports that FinnoKarelian traditions underwent a loss of information, but the process of loss remains ambiguous. The majority of the early Germanic examples were documented in Iceland (West Norse), and traditions in Germanic cultures on the Baltic Sea (East Norse) may have maintained markedly different, distinct traditions (§1). The loss of information may have happened already in a Germanic tradition (cf. §11.4) potentially introduced into the Finno-Karelian traditions (§4) - or vice versa superseding conventional ATU 1148b or reshaping the narrative pattern according to new priorities (cf. §5).

The early Greek example of ATU 1148b (§10) provides an interesting point of historical reference, even if it is not entirely certain when or within what horizons the underlying tradition may have been conventional, nor even that the tradition manipulated by Nonnos was indeed linguistically or culturally 'Greek' (cf. Rouse 1940, p.xiii; Tolley 2009, pp.93-102). The Greek example emphasises that $b k v$ is most likely a uniquely Germanic or uniquely Germanic Scandinavian adaptation of ATU 1148b (§11.1), of which other cultural forms are independent. There is strong evidence of a Germanic ATU 1148b tradition which shared many features with Finnic ATU 1148b traditions. This further increases the probability that $D k v$ was a conscious (parodic) adaptation of ATU 1148b intended to make fun of Thorr in the wake of the process of conversion to Christianity, founding a new tradition of ATU 1148b which persisted into the 20th century. This implies that any relationship to Finnic traditions predates the 13th century. The $P k v$ tradition with its history of conservative maintenance of the narrative for a minimum of six centuries emphasises that the evolution of a tradition such as ATU 1148b may have been characterised by fits and starts of radical (and socially relevant) transformations rather than being a slow, gradual and fluid progression.

The deeper roots of the tradition remain obscure. The conception of the thunder-instrument on which the narrative is dependent $(\S 1, \S 9)$ correlated with conventional conceptions in Estonian/Setu traditions ( $\$ 5$, cf. §7) where thunder was conceived as 'blown' on an instrument. However, this does not mean ATU 1148b developed around this particular conception. Norbertas Vèlius draws attention to a correlation between the devil's fear of thunder and the devil's fear of the sound

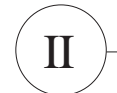

BALTIC WORLDVIEW: FROM MYTHOLOGY TO FOLKLORE 
of a mill (grinding stones) in Baltic traditions. He proposes that this is not simply typological but reflects some form of historical association of mills or milling with the thunder-god. (Vèlius 1987, pp.132-133.) This finds some support in the Latvian term milna ('stick; handle of a hand-mill') for Pērkons' club (Mühlenbach, Endzelīn 1923-1932 II, p.627), etymologically related to both Mjollnir (Thórr's hammer) and terms for 'mill' and 'milling' (West 2007, pp.253-254), and Finno-Karelian jyristimet appearing as two stones like those of a mill. ${ }^{44}$ An underlying aetiology of 'thunder' from a mill may be supported by a Komi-Zyryan ${ }^{45}$ aetiology of thunder from a 'self-grinding' mill worked with great effort (like the 'self-playing instrument' [§10]?) by a goat that lives with the supreme sky-god (Konakov et al. 2003, p.96). Although ATU 1148b is not attested in Komi, the role of the goat is striking because evidence of ATU 1148b is distributed across precisely those Indo-European mythologies (Baltic, Germanic, Greek) in which the thunder-wielding god is associated with goats (West 2007, pp.240, 248, 250). Like the Estonian blown instrument, the aetiology of thunder from a mill is non-percussive, and once 'thunder' is identified with 'music' there is no reason a 'mill' might not be 'played' - in which case, Estonian conceptions could thus be rooted in the ambiguity of the term pill.

Similarly, the Norse term hamarr ('hammer') had a conventional meaning of a stone wedge or cliff (see Motz 1997) and Thorsteinn's curious instrument involved striking with a spike (§11.3). These might be compared to traditions of the 'nail'-star's association with fire-striking ( $§ 1$ ) (Tolley 2009, pp.275-276, 281), which is connected to the technology of iron-working and the use of iron in fire-striking (cf. Salo 1990; 2006). Indeed, evidence of ritual fire-striking artefacts in the Circum-Baltic from the beginning of the Iron Age have been identified with thunder-god worship, and even the rise of the thunder-god to dominance in the region (Salo 1990, pp.119-129; Kulmar 2003, pp.28-29; Salo 2006, pp.33-48) (cf. §1). If the associations of grinding

${ }^{44}$ niinkun leipäkakkaraa vaan ('just like pancakes’) (SKS KRA Krohn, Kaarle 2201. 1884); Finno-Karelian aetiologies of thunder from god's wagon describe it as coming specifically from its wheels grating against stones in the heavens (e.g. SKS KRA Valkonen, Jaakko TK 112:393. 1961). It is interesting to consider that an accumulation of information from ATU 1148b could explain the mysterious motif of sleep in the epic theft/recovery of the FinnoKarelian sampo from the otherworld, or perhaps even, in some archaic and remote cultural stratum, the sampo's identification as a 'mill' (see Frog forthcoming).

45 The Komi are a Finno-Ugric culture which was still in direct contact with Finnic cultures in the first millennium of the present era; linguistic evidence suggests a primary direction of exchange from Finnic to Komi languages (Laakso 2001, p.202). and striking stones across these cultures are relevant, it is very possible that ATU $1148 \mathrm{~b}$ formed under a corresponding aetiology of thunder which held currency in an early period, probably long predating the earliest documented example from the 5th century (§10). However, these conceptions in any given culture at any given time are so diverse and stratified, entangled in their long and unique histories of transmission, reinterpretation, synthesis and rejection, spanning both genres and cultures, that the conceptual foundations of the identification of 'thunder' with an 'instrument' recedes like a Minotaur into the shadows of a labyrinth, and seems to have long since become irrecoverable, leaving the emergence of ATU 1148b, as the theft of a thunder 'instrument', a mystery.

\section{The evolution of ATU 1148 b as a historical process}

The single Greek example suggests that ATU 1148b was subject to significantly more cultural activity across other regions and linguistic-cultural groups in an earlier period. This emphasises that ATU 1148b traditions only persisted in the Circum-Baltic area. In this light, a possible connection between ATU 1148b and the Komi goat-mill does not seem inherently unreasonable, even if it remains ambiguous. It is also more remarkable that ATU 1148b persisted among Sámic, Finnic, Baltic and Germanic linguistic-cultural groups as an isogloss in spite of the radical transformations to which it was subject in each culture. Within this isogloss, transformations appear to have been more radical or to have begun earlier in cultures at the periphery (cf. Koptjevskaja-Tamm, Wälchli 2001, pp.638-640) - Sámic, Lithuanian and earlier Germanic. There appears to be a correlation between persistence of ATU 1148b in any one linguistic-cultural group and its persistence among one or more adjacent populations.

In their survey of linguistic developments through historical contact in the Circum-Baltic, Koptjevskaja-Tamm and Wälchli (2001, p.622) emphasised the culturally dynamic history of this area. The cultural dynamism of this history also seems relevant to understanding narrative traditions such as ATU 1148b. The persistence of ATU 1148b across all of these diverse linguistic-cultural groups appears to be at least partially dependent on their history of contact and interaction. Persistence was supported, maintained and conditioned within the system of traditions related to thunder and the thunder-god found in each of these cultures (§1, §9). However, we should not underestimate that the system of beliefs, conceptions, rituals and narrative activity associated with thunder was also supported and maintained through ongoing contact with adjacent 
cultures which had corresponding traditions. The significance of adjacence in the persistence of traditions is poorly understood. It appears to be relevant to aesthetic compositional priorities such as alliteration (Roper 2009, pp.90-93; Frog, Stepanova 2011, pp.209-211; cf. Koptjevskaja-Tamm, Wälchli 2001, pp.638-640). On the level of genre, adjacence has been considered a factor in the persistence of oral epic traditions, such as Slavic byliny and kalevalaic epic in Karelia (Bailey, Ivanova 1998, p.xxxvii; Frog 2010, p.235). It may also be relevant to the lamentation traditions addressed by Eila Stepanova (this volume), who demonstrates the genre's intimate connection with belief traditions. The evidence of ATU 1148b suggests that adjacence and a history of cultural contact is not only relevant to conceptions and beliefs related to thunder in the Circum-Baltic, but also to the persistence of individual narrative traditions associated with those conceptions and beliefs. ${ }^{46}$

Interpersonal contact is implicit in this process. It has been observed that introducing individuals from outside of a community or generating temporary communities of individuals (e.g. for work, travel or trade) has a stimulating effect on performance activity in different oral genres (e.g. Dégh 1969, 1995). A similar phenomenon has been observed in patterns of population movement which brings together diverse communities: this appears to have a more general stimulating effect on oral traditions (Siikala 2002b, pp.41-42; Frog 2010, pp.234-235). Such interactions on the level of isolated individuals and larger social groups were ongoing around the Baltic Sea for thousands of years, and it is reasonable to assume that this interaction had a stimulating effect on different traditions.

In the introduction to thunder-god traditions in the Circum-Baltic (§1), attention was drawn to Ülo Valk’s address of probable Indo-European cultural influences in Estonian traditions of thunder slaying the devil. Valk (1996) stresses that these influences are most likely heavily stratified and that 'the influence has been mutual rather than one-sided since the very beginning of the relations' (Valk 1996, p.20). The impact of interaction may not be merely one of simple transference as early 20th century scholarship was inclined to assume, particularly if corresponding traditions are already established in the other culture (Valk 1996, p.20). This was emphasised when addressing the potential impacts of Kreutzwald's published texts on Estonian and Setu oral traditions (§5), and also in the changes undergone by both Thórr's fishing expedition and the cultural activity of his hammer as a symbol in response to corre-

\footnotetext{
${ }^{46} \mathrm{Cf}$. Lina Būgienè's (this volume) discussion on beliefs in a supernatural 'milk-stealer' emergent in a system of narrative legends.
}

sponding Christian traditions (§11.4). Contact appears to stimulate sensitivity to the value and significance of traditions, as well as presenting options and alternatives of form, contents and applications. Stimulations, revaluations and transformations of ATU 1148b in Circum-Baltic cultures appear to have been part of that process. The persistence of ATU 1148b in these cultures, its maintenance and transformations, appear to be the product of patterns of interaction to such a degree that it becomes impossible to reduce its history to a simple linear model of origin in one culture and transmission to the next, and to the next, and to the next, and so forth. The Greek example implies that ATU 1148b was not limited to the Circum-Baltic, and the conceptions on which the instrument is founded may be extremely archaic, yet in the Circum-Baltic, ATU 1148b evolved through processes of cultural contact involving stimulation, response and exchange to such a degree and over such a history that this tradition is most reasonably approached as belonging, not to an isolated mythology of any one culture, but to a common Circum-Baltic mythological heritage.

\section{Abbreviations}

ATU - Aarne-Thompson-Uther tale-type (Uther 2004)

LFK - The Latvian Folklore Archives of the Institute of Literature, Folklore and Art

LTR - The Lithuanian Folklore Archives of the Institute of Lithuanian Literature and Folklore

SKS KRA - The Folk Poetry Archive of the Finnish Literature Society

\section{References}

AARNE, A., 1910. Verzeichnis der Märchentypen. FF Communications, 3. Helsinki: Academia Scientiarum Fennica. AARNE, A., 1911. Finnische Märchenvarianten: Verzeichnis der bis 1908 gesammelten Aufzeichnungen. FF Communications, 5. Helsinki: Academia Scientiarum Fennica.

AĐALSTEINSSON, R.I., 2009. Alliteration and Grammatical Categories. In: T.K. DEWEY, FROG, eds. Versatility in Versification: Multidisciplinary Approaches to Metrics. Berkeley Insights in Linguistics and Semiotics, 74. New York: Peter Lang, 91-102.

AJKHENVALD, A., HELIMSKI, E., PETRUKHIN, V., 1989. On Earliest Finno-Ugrian Mythologic Beliefs: Comparative and Historical Considerations for Reconstruction. In: M. HOPPÁL, J. PENTIKÄINEN, eds. Uralic Mythology and Folklore. Ethnologica Uralica, 1. Helsinki: Finnish Literature Society, 155-159.

ANDERSON, W., 1939. Zu dem Estnischen Märchen vom Gestohlenen Donnerinstrument. Acta et Commentationes Universitatis Tartuensis, 45:1. Tartu: University of Tartu.

ARĀJAS, K., MEDNE, A., 1977. Latviešu pasaku tipu rādītājs. The Types of the Latvian Folktales. Riga: Zinātne.

BAILEY, J., IVANOVA, T., eds., 1998. An Anthology of Russian Folk Epic. Armonk: Sharpe.

BALYS, J., 1939. Griaustinis ir velnias: Baltoskandijos kraštų tautosakos studija. Donner und Teufel in den Volk-

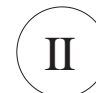

BALTIC WORLDVIEW: FROM MYTHOLOGY TO FOLKLORE 
serzählungen der baltischen und skandinavischen Völker. Tautosakos darbai, VI, 3-236.

BARAG, L.G., BEREZOVSKII, I.P., KABASHNIKOV, K.P., NOVIKOV, N.V., 1979. Sravnitel'nyi ukazatel' siuzhetov: Vostochnoslavianskaia skazka. Leningrad: Nauka.

BERTELL, M., 2003. Tor och den nordiska Åskan: Föreställingar kring Vårldsaxeln. Stockholm: Religionshistoriska Institutionen, Stockholms Universitet.

BIEZAIS, H., 1972. Die Himmlische Götterfamilie der Alten Letten. Acta Universitatis Upsaliensis Historia Religionum, 5. Uppsala: Uppsala Universitet.

BUGGE, S., MOE, M., 1897. Torsvisen i sin norske Form: Udgivet med en Afhandling om dens Oprindelse og Forhold til de andre nordiske Former. Festskrift til Hs. Maj. Kong Oscar II ved Regjerings-Jubilæet den 18de Sept. 1897: 5. Christiania: Aschehoug \& Co.

CAPELLE, T., 2005. Thorshammer. In: Reallexikon der Germanischen Altertumskunde XXX, $2^{\text {nd }}$ ed. Berlin: de Gruyter, 487-490.

CHARNOLUSKII, V.V. ed., 1962. Samskie skazki. Moskva: Khudozhestvennaia literatura.

CLEASBY, R., VIGFÚSSON, G., 1896. An Icelandic English Dictionary Chiefly Founded on the Collections Made from Prose Works of the $12^{\text {th }}-14^{\text {th }}$ Centuries. Oxford: Clarendon Press.

CLUNIES ROSS, M., 1994. Pórr's Honour. In: H. UECKER, ed. Studien zum Altgermanischen: Festschrift für Heinrich Beck. Ergänzungsbände zum Reallexikon der germanischen Altertumskunde, 11. Berlin: de Gruyter, 48-76.

CLUNIES ROSS, M., 2002. Reading Drymskviða. In: P. ACKER, C. LARRINGTON, eds. The Poetic Edda: Essays on Old Norse Mythology. New York: Routledge, 180194.

DAHL, Ö., KOPTEVSKAJA-TAMM, M., eds., 2001. The Circum-Baltic Languages: Typology and Contact. Studies in Language Companion Series, 54/55. Amsterdam: John Benjamins.

DÉGH, L., 1969. Folktales and Society: Story-Telling in a Hungarian Peasant Community. Bloomington: Indiana University Press.

DÉGH, L., 1995. Narratives in Society: A Performer-Centered Study of Narration. FF Communications, 255. Helsinki: Academia Scientiarum Fennica.

DIE DONNERTROMMEL, 1858. Das Inland, 6, 89-90.

DUBOIS, T.A., 1999. Nordic Religions in the Viking Age. Philidelphia: University of Pennsylvania Press.

FAULKES, A. ed. 1982. Snorri Sturluson, Edda: Prologue and Gylfaginning. London: Viking Society for Northern Research.

FAULKES, A. ed. 1998 Snorri Sturluson, Edda: Skáldskaparmál I: Text. London: Viking Society for Northern Research.

FELLMAN, J., 1906. Ur Lappisk Mytologi och Lappländsk Sägen. In: J. FELLMAN, ed. Jacob Fellman. Anteckningar under min vistelse i Lappmarken, vol. II. Helsingfors: Finska litteratursällskapet, 1-190.

FIDJESTØL, B., 1999. The Dating of Eddic Poetry: A Historical Survey and Methodological Investigation. O.E. HAUGEN, ed. Bibliotheca Arnamagnæana, 41. Copenhagen: Reitzels.

FROG, 2010. Baldr and Lemminkäinen: Approaching the Evolution of Mythological Narrative through the Activating Power of Expression: A Case Study in Germanic and Finno-Karelian Cultural Contact and Exchange. London: University College London dissertation [online]. Avail- able from: http://eprints.ucl.ac.uk/19428/1/19428.pdf [Accessed 19 March 2010].

FROG (forthcoming). Confluence, Continuity and Change in the Evolution of Myth: Cultural Activity and the FinnoKarelian Sampo-Cycle. In: FROG, A.-L. SIIKALA, E. STEPANOVA, eds. Mythic Discourses: Studies in FinnoUgrian Traditions. Studia Fennica Folkloristica. Helsinki: Finnish Literature Society.

FROG, STEPANOVA, E. 2011. Alliteration in (Balto-) Finnic Languages. In: J. ROPER, ed. Alliteration and Culture. Houndmills: Palgrave MacMillan, 195-218.

GRUNDTVIG, S. ed., 1853. Danmarks gamle Folkeviser I. Kjöbenhavn: Theiles Bogtrykkeri.

GSCHWANTLER, O., 1968. Christus, Thor und die Midgardschlange. In: H. BIRKAN, O. HÖFLER, eds. Festschrift für Otto Höfler zum 65. Geburtstag. Wien: Notring, 145-168.

HAAVIO, M., 1967. Suomalainen Mytologia. Porvoo: Werner Söderström.

HALLBERG, P., 1954. Om Prymskviða. Arkiv för Nordisk Filologi, 69, 51-77.

HANSEN, W., 1995. The Theft of the Thunderweapon: A Greek Myth in its International Context. Classica et Mediaevalia, 46, 5-24.

HANSEN, W., 2002. Ariadne's Thread: A Guide to International Tales Found in Classical Literature. Ithaca and London: Cornell University Press.

HARRIS, J., 2009. The Rök Stone's iatun and Mythology of Death. In: W. HEIZMANN, K. BÖLDL, H. BECK, eds. Analecta Septentrionalia: Beiträge zur nordgermanischen Kultur- und Literaturgeschichte. Ergänzungsbände zum Reallexikon der germanischen Altertumskunde, 65. Berlin: de Gruyter, 467-501.

HARVA, U., 1948. Suomalaisten muinaisusko. Porvoo: WSOY.

HOLMBERG [HARVA], U., 1916. Suomensuvun uskonnot II: Lappalaisten uskonto. Porvoo: Werner Söderström.

ITKONEN, T. I., 1931. Koltan- ja koulanlappalaisia satuja. Suomalais-Ugrilaisen Seuran Toimituksia, 60. Helsinki: Suomalais-Ugrilainen Seura.

ITKONEN, T. I., 1946. Heidnische Religion und späterer Aberglaube bei den Finnischen Lappen. Suomalais-Ugrilaisen Seuran Toimituksia, 87. Helsinki: Suomalais-Ugrilainen Seura.

JACKSON, P., 2005. Thorsmythen. In: Reallexikon der Germanischen altertumskunde XXX, 2nd ed. Berlin: de Gruyter, 490-498.

JAKOBSEN, A., 1984. Prymskviða som Allusjonsdikt. Edda, 75-80.

JESSEN-SCHARDEBØLL, E.J., 1767. Afhandling om de norske Finners og Lappers hedenske religion med en tegning af en rune-bomme - Finnorum Lapponumque norwegicorum religion pagana, tractatus singularis una cum delineation tympani runici. Kiøbenhavn: Salikath.

JÓNSSON, F., ed., 1905-1912. Rímnasafn: Samling af de celdste islandske Rimer, I. København: Møllers Bogtrykkeri.

JÓNSSON, G., VIHJÁLMSSON, B., 1943-1944. Fornaldarsögur Norðurlanda, vol. I-III. Reykjavik: Forni.

KERBELYTĖ, B., 1999-2002. Lietuviu pasakojamosios tautosakos katalogas, vol. I-III. Vilnius: Lietuvių literatūros ir tautosakos institutas.

KECSKEMÉTI, I., PAUNONEN, H., 1974. Die Märchentypen in den Publikationen der Finnisch-ugrischen Gesellschaft. Suomalais-Ugrilaisen Seuran Aikakauskirja, 73, 206-265. 
KOCH, E., 1990. Fire (Translation of a paper printed in Skalk no. 5/1990, in the version edited by Skalk) [online]. Available from: http://evakoch.dk/HTML/ild-UK.htm [Accessed 15 May 2010]

KONAKOV, N., IL'INA, I.V., LIMEROV, P.F., ULYASHEV, O.I., SHABAEV, YU.P., SHARAPOV, V.E., VLASOV, A.N., 2003. Komi Mythology. The Encyclopedia of Uralic Mythologies, 1. Budapest: Académiai Kiádo.

KOPTJEVSKAJA-TAMM, M., WÄLCHLI, B., 2001. The Circum-Baltic Languages: An Areal-Typological Approach. In: Ö. DAHL, M. KOPTEVSKAJA-TAMM, eds., 2001, 615-750.

KREUTZWALD, F.R., 1866. Eestirahva ennemuistesed jutud. Suomalaisen Kirjallisuuden Seuran Toimituksia, 42. Helsingi Linnas: Soome-maa Kirja-seltsi.

KROHN, K., 1906. Lappische Beiträge zur germanischen Mythologie. Finnisch-Ugrische Forschungen, 6, 155-180. KROHN, K., 1915. Suomensuvun uskonnot I: Suomalaisten runojen uskonto. Suomalaisen Kirjallisuuden Seuran Toimituksia, 137. Helsinki: Suomalaisen Kirjallisuuden Seura.

KROHN, K., 1922. Skandinavisk Mytologi. Helsinki: Holger Schlidts Förlagsaktiebolag.

KROHN, K., 1928. Kalevalastudien VI: Kullervo. FF Communications, 76. Helsinki: Academia Scientiarum Fennica.

KROHN, K., 1931. Übersicht über einige Resultate der Märchenforschung. FF Communications, 96. Helsinki: Academia Scientiarum Fennica.

KULMAR, T., 2005. On Supreme Sky God from the Aspect of Religious History and Prehistoric Estonian Material. Folklore: Electronic Journal of Folklore, 31, 15-30.

LAAKSO, J., 2001. The Finnic Languages. In: Ö. DAHL, M. KOPTEVSKAJA-TAMM, eds., 2001, 179-212.

LAURINKIENĖ, N., 1996. God Perkūnas of Ancient Lithuanians: Abstract of the Thesis for a Habilitated Doctor of Humanities Degree (Folkloristic). Vilnius: Institute of Lithuanian Literature and Folklore.

LIESTØL, K., 1970. Den norrøne Arven. Oslo: Universitetsforlaget.

LINDOW, J., 1994. Thor's hamarr. The Journal of English and Germanic Philology, 93, 485-503.

LINDOW, J., 2000. Thor's Visit to Útgarðaloki. Oral Tradition, 15, 170-186.

LIUNGMAN, W., 1961. Die schwedischen Volksmärchen: Herkunft und Geschichte. Deutsche Akademie der Wissenschaften zu Berlin, Veröffentlichungen des Instituts für deutsche Volkskunde, 20. Berlin: Akademie-Verlag.

LOORITS, O., 1926. Liivi rahva usund I. Acta et Commentationes Universitas Tartuensis, B 11.1. Tartu: University of Tartu.

LOORITS, O., 1932. Das Märchen vom gestohlenen Donner-instrument bei den Esten. Special printing from Sitzungsberichte der gelehrten estnischen Gesellschaft, 1930. Tartu: Gelehrte estnische Gesellschaft, 47-121.

LOORITS, O., 1949-1957. Grundzüge des Estnischen Volksglaubens, vol. I-III. Skrifter utgivna av Kungl. Gustav Adolfs akademien för folklivsforskning, 18. Lund: Lundequist.

MAGERØY, H., 1991 [1956]. prymskviða. In: H. MAGERØY. Norroena et Islandica: Festskrift til Hallvard Magerøy på 75-årsdagen den 15. Januar 1991. Øvre Ervik: Alvheim \& Eide, 1-15.

MANSIKKA, V.J., 1922. Die Religion der Ostslaven I: Quellen. FF Communications, 43. Helsinki: Academia Scientiarum Fennica.
MASING, U., 1944. Die Entstehung des Märchens vom gestohlenen Donnerinstrument (Aarne-Thompson 1148b). Zeitschrift für deutschen Altertum und Literatur, 81, 2331

MASING, U., 1977. Kōuelind ja veesarvik (AaTh 1148B). In: Studia orientalia et antiqua II. Tartu riikliku ülikooli toimetised, 416. Tartu: University of Tartu, 117-169.

MCKINNELL, J., 1994. Both One and Many: Essays on Change and Variety in Late Norse Heathenism. Philologia, 1. Roma: Il Calamo.

MCKINNELL, J., 2001. Eddic Poetry in Anglo-Saxon Northern England. In: J. GRAHAM-CAMBELL, R. HALL, J. JESCH, D. N. PARSONS, eds. Vikings and the Danelaw: Select Papers from the Thirteenth Viking Congress, Nottingham and York, 21-30 August 1997. Exeter: Oxbow, 327-344.

MEULENGRACHT SØRENSEN, P., 1983. The Unmanly Man: Concepts of Sexual Defamation in Early Northern Society. Viking Collection, 1. Odense: Odense University Press.

MEULENGRACHT SØRENSEN, P., 2001 [1986]. Thor's Fishing Expedition. In: P. MEULENGRACHT SØRENSEN. ed. At fortcelle historien: studier i den gamle nordiske litteratur. Telling History: Studies in Norse Literature. Trieste: Parnaso, 59-70.

MOGK, E., 1924. Die Überlieferungen von Thors Kampf mit dem Reisen Geirröð. In: Festskrift tillägnad Hugo Pipping på hans sextioårsdag den 5 november 1924. Skrifter Utgivna av Svenska Litteratursällskapet i Finland, 175. Helsingfors: Svenska Litteratursällskapet i Finland, 379-388.

MOTZ, L., 1997. The Germanic Thunderweapon. Saga Book, 24, 329-350.

MÜHLENBACH, K., ENDZELĪN, J., 1923-1932. Latviešu valodas vārdnīca. Lettisch-deutsches Wörterbuch. Rīga: Lettische Kulturfond.

NECKEL, G., KUHN H., eds., 1963. Edda: Die Lieder des Codex Regius nebst vewandten Denkmälern $1.4^{\text {th }}$ ed. Heidelberg.

NIELSEN, G. H., 1911. Torsvisen på Færøerne. In: Festskrift til H. F. Feilberg: Fra nordiske Sprog- og Folkemindeforskere på 80 års dagen den 6. August 1911. Stockholm: Svenska Landsmålen, 72-76.

NORDEIDE, S.W., 2006. Thor's Hammer in Norway: A Symbol of Reaction against the Christian Cross? In: A. ANDRÉN, K. JENNBERT, C. RAUDVERE, eds. Old Norse Religion in Long-Term Perspectives: Origins, Changes, and Interactions: An International Conference in Lund, Sweden, June 3-7, 2004. Lund: Nordic Academic Press, 218-223.

OLRIK, A., 1906. Tordenguden og hans Dreng i Lappernes Myteverden. Danske Studier, 65-69.

OLRIK, J., RÆDER, H. eds., 1931. Saxonis Gesta Danorum. Hauniæ: Levin \& Munksgaard.

PEELE, C., ed., 1999. Guta saga: The History of the Gotlanders. Viking Society for Northern Research Text Series, 12. London: Viking Society for Northern Research.

RENDAHL, A.-C., 2001. Swedish Dialects around the Baltic Sea. In: Ö. DAHL, M. KOPTEVSKAJA-TAMM, eds. , 2001, 137-177.

ROPER, J., 2009. On Finnic and English Alliterative Metres. In: M. KILPIÖ, L. KAHLAS-TARKKA, J. ROBERTS, O. TIMOFEEVA, eds. The Anglo-Saxons and the North: Essays Reflecting the Theme of the 10th Meeting of the International Society of Anglo-Saxonists in Helsinki, August 2001. Medieval and Renaissance Texts and Studies, 364. Tempe: ACMRS, 89-108.

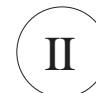

BALTIC WORLDVIEW: FROM MYTHOLOGY TO FOLKLORE 
ROUSE, W.H.D. ed., 1940. Nonnos, Dionysiaca I-III. Cambridge: Harvard University Press.

SALO, U., 1990. Agricola's Ukko in the Light of Archaeology: A Chronological and Interpretive Study of Ancient Finnish Religion. In: T. AHLBÄCK, ed. Old Norse and Finnish Religions and Cultic Place-Names. Scripta Instituti Donneriani Aboensis, 13. Åbo: Donner Institute, 92190.

SALO, U., 2006. Ukko: The God of Thunder of the Ancient Finns and His Indo-European Family. Journal of IndoEuropean Studies Monograph, 51. Wachington DC: Institute for the Study of Man.

von SEE, K., LA FARGE, B., PICARD, E., PRIABE, I., SCHULZ, K., 1997. Kommentar zu den Liedern der Edda II. Heidelberg: Universitätsverlag C. Winter.

SETÄLÄ, E.N. 1932. Turisas ja turilas. Virittäjä, 36, 201222

SIIKALA, A.-L., 2002a. Mythic Images and Shamanism: A Perspective on Kalevala Poetry. FF Communications, 280. Helsinki: Academia Scientiarum Fennica.

SIIKALA, A.-L., 2002b. The Singer Ideal and the Enrichment of Poetic Culture: Why Did the Ingredients for the Kalevala Come from Viena Karelia? In: L. HONKO, ed. The Kalevala and the World's Traditional Epics. Studia Fennica Folkloristica, 12. Helsinki: Finnish Literature Society, 26-43.

SIMEK, R., 1986. Elusive Elysia or which Way to Glæsisvellir: On the Geography of the North in Icelandic Legendary Fiction. In: R. SIMEK, J. KRISTJÁNSSON, H. BEKKER-NIELSEN. Sagnaskemmtun: Studies in Honour of Hermann Pálsson on his 65th Birthday, $26^{\text {th }}$ May 1986. Wien: Hermann Böhlaus, 247-275.

SIMPSON, J., 1966. Otherworld adventures in an Icelandic Saga. Folklore, 77, 1-20.

SUOMEN SANOJEN ALKUPERÄ, 1992-2000. Suomen sanojen alkuperä: Etymologinen sanakirja I-III. Kotimaisten Kielten Tutkimuskeskuksen Julkaisuja, 62. Helsinki: Suomalaisen Kirjallisuuden Seura.

TARKKA, L., 2005. Rajarahvaan laulu: Tutkimus Vuokkiniemen kalevalamittaisesta runokulttuurista 1821-1921. Suomalaisen Kirjallisuuden Seuran Toimituksia, 1033. Helsinki: Suomalaisen Kirjallisuuden Seura.

THOMPSON, S., 1928. The Types of the Folk-Tale: A Classification and Bibliography. FF Communications, 74. Helsinki: Academia Scientiarum Fennica.

THOMPSON, S., 1955-1958. Motif-Index of Folk-Literature: A Classification of Narrative Elements in Folktales, Ballads, Myths, Fables, Mediaeval Romances, Exempla, Fabliaux, Jest-Books and Local Legends, vol. I-VI. Revised and expanded edition. Copenhagen: Rosenkilde \& Bagger.

THORVALDSEN, B. Ø., 2008. Om Drymskviða, tekstlån og tradisjon. Maal og Minne, 2008, 142-166.

TOLLEY, C., 2009. Shamanism in Norse Myth and Magic I. FF Communications, 296. Helsinki: Academia Scientiarum Fennica.

TOLLEY, C. (forthcoming). On the Trail of Pórr's Goats. In: FROG, STEPANOVA E., A.-L. SIIKALA, eds. Mythic Discourses: Studies in Finno-Ugrian Traditions. Studia Fennica Folkloristica. Helsinki: Finnish Literature Society. TOPOROV, V.N., 1970. K balto-skandinavskim mifologicheskim sviaziam. In: V. RŪĶE-DRAVIN̦A, ed. Donum Balticum: To Professor Christian S. Stang on the Occasion of His Seventieth Birthday 15 March 1970. Stockholm: Almqvist \& Wiksell, 334-343.
UTHER, H.-J., 1997-1999. Donner. In: K. RANKE et al., eds. Enzyklopädie des Märchens: Handwörterbuch zur historischen und vergleichenden Erzählforschung. Vol. 3. Berlin and New York: Walter de Gruyter, 762-766.

UTHER, H.-J., 2004. The Types of International Folktales. Vol. I-III. FF Communications, 284-286. Helsinki: Academia Scientiarum Fennica.

VAITKEVIČIUS, V., 2009. Tracing the Baltic Religious Terms: The Lithuanian stabas 'Pagan Idol'. In: L. BŪGIENĖ, D. VAITKEVIČIENĖ, eds. International Conference Baltic Worldview: From Mythology to Folklore, July 8-10, 2009, Vilnius, Lithuania: Abstracts. Vilnius: Lietuviu literatūros ir tautosakos institutas, 36, 70.

VAITKEVIČIENĖ, D. ed., 2008. Lietuviu užkalbejjimai: gydymo formules. Lithuanian Verbal Healing Charms. Vilnius: Lietuviu literatūros ir tautosakos institutas.

VALK, Ü. 1996. Thunder Chasing the Devil: An Estonian Folk Belief in the Indo-European Context. In: S. SKRODENIS, ed. Professor August Robert Niemi and Comparative Folklore Investigations of the Balts and Baltic Finns: Papers of the International Conference Held on 1-2 December, 1994, Vilnius, Lithuania. Vilnius: Lithuania-Finland Society, 16-21.

VĖLIUS, N., 1987. Chtoniškasis lietuviu mitologijos pasaulis: Folklorinio velnio analize. Vilnius: Vaga.

VĖLIUS, N., 1989. The World Outlook of the Ancient Balts. Vilnius: Mintis.

VĖLIUS, N. ed., 1996. Baltu religijos ir mitologijos šaltiniai I: Nuo seniausiu laiku iki XV amžiaus pabaigos. Sources of Baltic Religion and Mythology I: From the Oldest Times to the End of the $15^{\text {th }}$ Century. Vilnius: Mokslo ir enciklopedijų leidykla.

VESTLUND, A., 1919. Åskgudens Hammare Förlorad: Ett Bidrag till nordisk Ritforskning. Edda, 11, 95-119.

de VRIES, J., 1928. Over de Datieering der Prymskviða. Tijdschrift voor nederlandsche Taal- en Letterkunde, 47 251-322.

de VRIES, J., 1933. The Problem of Loki. FF Communications, 110. Helsinki: Academia Scientiarum Fennica.

de VRIES, J., 1956-1957. Altgermanische Religionsgeschichte, vol. I-II. Grundriss der germanischen Philologie, 12(1-2). $2^{\text {nd }}$ ed. Berlin: de Gruyter.

WEST, M.L., 2007. Indo-European Poetry and Myth. Oxford: Oxford University Press.

Frog

University of Helsinki

Department of Folklore Studies

PL 4 (Vuorikatu 3)

00014 University of Helsinki

Finland

E-mail: misterfrogfrog@yahoo.de

Received: 26 April 2011; Revised: 31 May 2011; Accepted: 16 May 2011. 
BENDROJI BALTIJOS REGIONO

MITOLOGIJA? GRIAUSTINIO

INSTRUMENTO PAGROBIMAS

(ATU 1148B) KAIP BENDRASIS

BALTIJOS REGIONO MITAS

\section{Frog}

\section{Santrauka}

Straipsnyje aptariamas naratyvas apie mitinius santykius: Griaustinio instrumento pagrobimas (ATU 1148B). Trumpa teksto santrauka:

Velnias/milžinas pavagia miegančio Griaustinio instrumenta - muzikos, mechanini ar simbolini - ir paslepia ji savo valdose ar buveineje. Dievas, apsimesdamas tarnu, stoja tarnystèn pas vagi arba pakliūva i jo namus kartu su savo šeimininku. Pagroti Griaustinio instrumentu niekas nesugeba. Iššūki priima šeimininkas ar dievas (tarpininkaujant jo šeimininkui). Neįtardamas klastos ir tikédamasis teigiamo rezultato (pasilinksminimo), vagis ịduoda dievui instrumenta. Užgrojęs dievas užmuša vagi, jo šeimyna ir/ar kito pasaulio bendruomene.

ATU 1148B siužetas daugiausia aptinkamas abiejose Baltijos regiono indoeuropiečių ir finougrų kalbinèse-kultūrinėse grupėse. Šis faktas leidžia manyti, kad viena kultūra siužetą perème iš kitos arba jis buvo pasiskolintas iš bendro kultūrinio sluoksnio. Kad ir kaip būtų, ATU 1148B siužetas akivaizdžiai kertasi su kalbinėmis-kultūrinėmis ribomis: tokių pavyzdžių aptinkama individualiose samių (skolto, [galimai] inari), finų (suomių, karelų, estų, setų), baltų (latvių, lietuvių) ir germanų (islandų, fareriečių, norvegų, danų, švedų) kalbų šeimų tradicijose. Tačiau ATU 1148B siužeto nerandama slavų grupèse, kurios vis didesnę įtaką bendram Baltijos regionui darè tik pastaraji tūkstantmetị. Šiaip ATU 1148B siužetas dar aptiktas vienoje ankstyvoje graikų poemoje, kur jis sukomponuotas kartu su pasakojimu apie Dzeuso jègos pagrobimą. Koptjevskaja-Tamm, Wälchli (2001, p. 622) teigia, kad vienas iš įdomesnių bendrojo Baltijos regiono aspektų yra tas, jog „jis niekada nebuvo suvienytas, bet visada pasižymejjo kaip ypač dinamiška teritorija, nuolat persidalijanti ekonomines, politines, religines ir kultūrines dominavimo sferas". Pateikiant bendrą ịspūdi apie ATU 1148B siužetą, siekiama panagrinèti, kaip ilgalaikiai kultūriniai kontaktai, per kuriuos komunikavimo procesas vyko ir buvo palaikomas, darè tiesioginę ịtaką mitologijos, tikejjimų ir pasakojamosios tradicijos mainams.
Publikacija pradedama trumpu įvadu apie Griaustinio dievą bendro Baltijos regiono tradicijose $(\S 1)$ ir supažindinimu su darbo pobūdžiu (\$2). Šis tyrimas suskaidytas pagal kalbines-kultūrines grupes. Anksčiausias tokio pobūdžio pavyzdys yra Edos poemoje prymskviða (iš maždaug 1270 m. rankraščio); jis dažniausiai traktuojamas kaip autentiškiausia ar pati patikimiausia mito forma, iš kurios radosi kitos formos. Tačiau germaniški šaltiniai šiame tyrime dèl tam tikru problemų aptarti paskiausiai. Pirmiausia aptariama samių medžiaga (§3), nagrinèjamos rytinès Baltijos jūros pusès tradicijos, ir iš čia tyrimas pajuda nuo šiaurès i pietus: suomių-karelų (§4), estų ir setų (§5), latvių (§7) ir lietuvių (§8) medžiaga. Lyginimui ir analizei taip pat pasitelkta unikali lyvių pasakojamoji tradicija (§6). Po šios tyrimo dalies eina preliminarus apibendrinimas (§9). Paskui pristatomas graikiškas pavyzdys $(\S 10)$, kartu gretinant ir atitinkamą germanišką medžiagą (\$11). Tyrimas baigiamas ATU 1148B siužeto apžvalga šiose kultūrose (§12), pateikiami baigiamieji svarstymai apie atskiras ATU 1148B siužeto tradicijas ir ryšius tarp jų (§13).

Bendrojo Baltijos regiono kultūrų mitologija apibūdinama per Griaustinio dievo iškèlimą i aukščiausią poziciją indoeuropiečių ir finougrų kultūrose. Tai susiję su tarpkultūriniais ryšiais, suformavusiais stratifikuotas mitologines sąvokas $(§ 1)$. Šio proceso aspektus atskleidžia Griaustinio etiologijos įvairovè. Ją patvirtina archeologiniai duomenys apie tam tikrus ritualinius veiksmus, atskleisdami, kad ịvairiais laikotarpiais besikeičianti etiologija buvo nevienodai reikšminga $(\S 9, \S 12)$. ATU $1148 \mathrm{~B}$ siužetas figūruoja šiose stratifikuotose sampratose. Šio naratyvo pagrindą sudaro užslèpta Griaustinio instrumento samprata: a) objektas, kuri velnias gali gauti, bet b) nesugeba tinkamai panaudoti; objektas, kuris c) gali būti atvaizduotas kaip esantis Griaustinio; d) jo tinkamas panaudojimas pats savaime nèra pavojingas ir netgi gali būti pageidautinas (§9). Griaustinio instrumentas ATU 1148B siužete neatskleidžia dominuojančios Griaustinio etiologijos, išskyrus estų tradiciją ( $(12)$. Todèl Griaustinio samprata ir Griaustinio dievo atributai $(\S 1)$ čia yra traktuojami kaip skirtingų kultūrų ATU 1148B siužeto kultūrinės veiklos veiksnys ir jo istorinè plètotè $(\S 9, \S 12)$. Aptariant istorinès raidos procesus, taikoma informacijos sukaupimo koncepcija - telkiami motyvai, įvaizdžiai ar naratyvinè medžiaga kaip šaltinis, praturtinantis naratyvą (šiuo atveju) ir leidžiantis tirti naratyvo potencialią reikšmę, plitimą bei raidą. Informacijos sukaupimo koncepcija gretinama su informacijos praradimo koncepcija - motyvų, vaizdinių, asmenų ar kitos tradicinès medžiagos praleidimu ar sumažinimu.

Bendrojo Baltijos regiono izoglosos ribose ATU 1148B siužeto transformacijos pasirodo esančios esminès

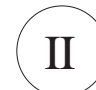

BALTIC WORLDVIEW: FROM MYTHOLOGY TO FOLKLORE 
arba prasidejjusios anksčiau periferinėse kultūrose. Samių tradicija šiaurinëje periferijoje prarado informaciją neįtraukdama ,instrumento“ ir vaizduodama tik pati Griaustinio dievą, tuo tarpu pavogtą (pagrobtą) objektą čia atgauna jo kompanionas (§3). Pietinejje periferijoje, lietuviu tradicijoje, taip pat prarasta informacija: Griaustinio dievo dingęs daiktas nustotas tapatinti su griaustinio šaltiniu ar dievo ginklu ir buvo priskirtas kitiems naujiems objektams (§8). Naratyvas pratęse savo egzistenciją kaip kūrinys, paaiškinantis priešiškumo tarp Griaustinio dievo ir velnių kilmę, tačiau pavogto objekto atgavimas tapo nereikšmingas. Tačiau gali būti, kad kita pasakojamoji tradicija (ATU 1165), atitinkamai sukaupdama informaciją, peremė šio nutikimo motyvus (§9). Ši plètotè skirtingose tradicijose tiesiogiai sietina su etiologija ir griaustinio samprata bei Griaustinio dievu, tuo tarpu ženklus lyginamuju duomenų kiekis leidžia manyti, kad ATU 1148B siužetas rutuliojosi iš griaustinio kaip girnu ar panašaus instrumento kuriamos „muzikos“ sampratos (§12). Samių ir lietuvių variantai patvirtina, kad indeksiškai susijusios motyvų sistemos pasitelkè naujus objektus ir pritaikè juos prie naujų kontekstų.

Ankstyvasis graikų ATU 1148B pavyzdys (§10) suteikia ịdomios istorinès informacijos apie galimą šio siužeto datavimą ir paplitimą ankstyvuoju periodu. Jame pasakojama apie: a) vagystę miego metu; b) griaustini kaip savaime grojantį instrumentą, kuris, nepaisant to, c) reikalauja grojimo ịgūdžių; d) turi būti deramai valdomas ir e) juo negali groti velnias; f) instrumento paslèpimą; g) dievą-tarną, kuris h) užsimaskuoja kaip piemuo ir i) meta iššūkị siūlydamasis pagroti, kas baigiasi j) velnio dievui atiduodamo pagrobto galios atributo k) muzikinio instrumento, 1) kad palinksmintu grodamas. Uku Masing (1944) pažymëjo, kad atitikimas tarp graikiško pavyzdžio ir estų bei setų medžiagos prieštarauja hipotezei, jog finų ir suomių tradicijos gavo siužetą iš germanų, kurie ši viduramžiais perèmé iš Prymskviða tradicijos. Poema Prymskviða išsiskiria dominuojančiu karikatūrinio aprašymo vaizdiniu, kaip dievas Toras, norèdamas atgauti milžino pavogtą kūjelį, persirenge moterimi ir igavo milžino nuotakos pavidalą. Šiame tyrime supažindinama su anksčiau nepastebèta aplinkybe, kad germanu tradicija yra artimesnè finų ir graikų medžiagai (§11.3). Publikacijoje prymskviða išryškejja kaip unikalus germanų kultūrų kūrinys, kartu pažymima, kad sukarikatūrintas ATU 1148B siužetas adaptuotas ir liaudies dainuojamojoje tradicijoje (\$11.1), kur besikeičiančioje (krikščionių) kultūrinejje aplinkoje naratyvas ịgavo naują reikšmę ir svarbą (§11.4). Kaip ir samių bei lietuvių ATU 1148B siužetų raidos atveju, panašu, kad Prymskviða susiformavimui įtakos turejo platesnè tradicijos ekologija ir konceptuali sistema, kurioje ji funkcionavo. Mano nuomone, kultūrinèje aplinkoje yra koreliacija tarp socialinių vartojimo modelių ir platesnių Griaustinio dievo bei griaustinio etiologijos koncepcijų, tarp naratyvo tradicijos evoliucijos ir istorinių procesų (§12).

ATU 1148B siužeto kilmè išlieka neaiški ir negali būti aiškiai priskirta nei indoeuropiečių, nei finougrų kultūriniam paveldui. Taip pat neaišku, ar jis galèjo būti perimtas iš išnykusios kalbinės-kultūrinès grupès, ar galbūt susidare kaip etiologija, susijusi su rankinių girnelių, kaip naujausios technologijos, ịsisavinimu (paraleliai su etiologijomis, kurios kilo iš geležies apdirbimo technologijų). Kad ir kaip būtų, šios tradicijos susiformavimas indoeuropiečių ir finougrų kalbinèsekultūrinėse grupèse yra aiškiai susijęs su šių populiacijų kontaktais ir tarpusavio sąveika. Mano nuomone, kultūriniai kontaktai ir tradicijų panašumas gretimose kultūrose tiesiogiai nulèmè ATU 1148B siužeto išsilaikymą bendro Baltijos regiono kultūrose (§13). Atrodo, kontaktas paskatino labiau vertinti tradicijas ir ju svarbą, taip pat ir formos, turinio bei pritaikymo pasirinkimą ir alternatyvas. ATU 1148B siužeto duodami stimulai, vis naujos interpretacijos ir transformacijos bendro Baltijos regiono kultūrose yra šio proceso dalis. ATU 1148B siužeto išsilaikymas, gyvavimas ir transformacijos šiose kultūrose yra rezultatas tarpusavio sąveikos, vykstančios tokiu lygmeniu, kad tampa neimanoma jos istorijos supaprastinti iki linijinès kilmès vienoje kultūroje ar perdavimo vis kitai kultūrai modelių. Graikų pavyzdys leidžia suprasti, kad ATU 1148B siužetas neapsiriboja vien bendru Baltijos regionu, o instrumento sukūrimo koncepcijos gali būti ypač senos. Bendrame Baltijos regione ATU 1148B siužetas plètojosi dèl kultūrinių kontaktų, ịskaitant stimulus, reakciją ir mainus tokiu lygmeniu ir tokiomis istorinès raidos aplinkybemis, kad ši tradicija įtikinamai atrodo ne kaip esanti kokios nors kultūros izoliuota mitologija, o kaip bendro Baltijos regiono mitologinis paveldas.

Vertė Jūratė Šlekonytė 